\title{
Coronary microvascular and endothelial function regulation: Crossroads of psychoneuroendocrine immunitary signals and quantum physics [Part B]
}

\author{
Carlo Dal Lin, Anna Poretto, Marta Scodro, Martina Perazzolo Marra, Sabino Iliceto and Francesco Tona \\ Department of Cardiac, Thoracic and Vascular Sciences, Padua University School of Medicine, Via Giustiniani 2, 35100 Padua, Italy
}

\begin{abstract}
Part B]
Stress is the key element that unites all the influences that have a cellular impact in the coronary microcirculation, determining serious consequences for health. In particular, mental stress does not differ from the physical stress and is always part of the biological processes that are examined in the research and daily clinical practice. Many cardiovascular diseases occur after a long process of stress, compensation and exhaustion, after accumulating some allostatic load. The stress reaction is common both at a macroscopic level both at the cellular level. We move forward considering the biological cellular balance, especially cardiovascular one, in molecular and atomic terms, with reference to the newest achievements in the field of quantum physics. The above leads inevitably to raise three important issues that must be solved in order to progress effectively in scientific research.
\end{abstract}

\section{The link between stress, cardiovascular disease and endothelial function}

Chronic stress is associated with the pathogenesis of CVD and increases CVD mortality

A wide variety of treatments against atherosclerosis-based CVD have been introduced by medical science during past years, with a significant reduction in mortality associated with these diseases. However, ischemic CVD remains a leading cause of death worldwide.

In addition to traditional risk factors such as dyslipidemia, hypertension, smoking, diabetes, obesity and physical inactivity, stress is thought to be a pivotal. Several types of stress are involved in the development of CVD, including oxidative stress, mental stress, hemodynamic stress and social stress.

A very interesting thing to note is that the condition of stress is the basis of each of the traditional cardiovascular risk factors [1-17].

The common effect of all these factors is to induce oxidative stress [18] in the vasculature leading to inflammation, endothelial dysfunction, atherogenesis, hypertension and remodeling of blood vessels.

Meanwhile, mental stress is a well-known major contributor to the development of cardiovascular disease [19-25]. It's the case of depression [26] which, for example, induces inflammation [27,28,29], oxidative stress, increases platelet reactivity [30,31,32], extends QTc interval [33], it is accompanied by an activation of the endocannabinoid system [34, 35-40] or induces mental stress myicardial ischemia. Even depression alone could lead to coronary artery calcification [41]. Moreover, Redmond et al. described that perceived stress is associated with incident coronary heart disease and all-cause mortality [42]. As shown by Lazzarino et al. mental stress is associated with cardiac cell damage with detectable plasma levels of troponin-T (cTnT) using high-sensitivity assays in healthy subjects, independently of coronary atherosclerosis [43]. As we will see, the concept of "personality" is intimately linked to the concept of mental stress. Some personality patterns [44], that is, depressive or aggressive moods, are linked with higher incidence of cardiovascular diseases [45-47] through chronic stress axis activation $[48,49]$. On the contrary, a positive affect and good interpersonal relations [50] rebalance the neuroendocrine stress axis, reduces inflammation and improves cardiovascular balance [5154].

Heart and vessels are constantly exposed to hemodynamic stress by the blood flow and/or pulsation, and hemodynamic stress exerts profound effects on the biology of vascular cells and cardiomyocytes [55]. And it's quite intuitive considering that in a state of mental/ social or physical stress, the hemodynamic stress increases as a simple result of the nonspecific physiological stress response (increased sympathetic tone, increased blood viscosity and thrombogenesis etc.) [56].

In addition, social stress (due to a lack of social support [57], poverty or living alone, unemployment [58]) has a negative impact on the incidence and prognosis of cardiovascular disease [59].

Furthermore, there are interactions between mental, oxidative and hemodynamic stress. The production of reactive oxygen species

Correspondence to: Carlo Dal Lin, MD, Department of Cardiac, Thoracic and Vascular Sciences, Padua University School of Medicine, Via Giustiniani 2, 35100 Padua, Italy, Tel: +39-049 8218642, Fax: +39-049 8211802; E-mail: carlodallin@libero.it

Key words: endothelial function, coronary microcirculation, coronary flow reserve, cardiovascular disease, psychoneuroendocrineimmunology, epigenetics, stress, allostatic load, integrative medicine, complementary and alternative medicine

Received: August 28, 2015; Accepted: September 18, 2015; Published: September 24, 2015 
is increased under high levels of mental stress in close association with oxidative stress. These factors of the stress response and their interactions play central roles in the pathogenesis of atherosclerosisbased cardiovascular disease [60]. Their action is associated with epigenetic changes (change of some circulating miRNAs, with relative change of the expression of inflammation genes) that occur rapidly after exposure to a stress, as demonstrated in animal models by Cho et al. [61].

\section{The mind is the area where the "danger" is perceived and triggers and modulates stress reactions. Brain and mind: new insights from modern neurobiology}

The relationship between brain and mind has philosophical, religious, scientific and practical implications. Philosophers and scientists have wrestled with the so called mind-body problem for millennia [62,63]. Nowadays, technical and cultural advances in neurosciences lead us to consider the brain and its neurons either as the basis from which thoughts and various types of consciousness arise, or as the destination of the psychological functions rising from its circuits. Neural circuitry and plasticity, molecular profiles, and neurochemistry can be changed by experiences and thoughts, which influence behavior as well as neuroendocrine and autonomic function [64].

Psychological stress influences biological systems that can damage the brain [64], the immune system [65] and dysregulate hormones and metabolism $[66,67]$. The activity of biological systems can modify our thoughts: for example, depression produces inflammation and inflammation itself could cause depression $[28,68]$.

The brains of subjects who are awake but at rest show spontaneous, synchronous, low-frequency oscillations. The mental processes of attention and thinking are increasingly becoming associated with the activity in different distributed brain regions (Figure 1-A). A tasknegative, or default mode network (DMN) has been associated with independent, spontaneous thought processes, also known as mind wandering $[69,70]$ The activity of this system increases during selforiented thinking, e.g. during a resting state, but decreases during externally oriented attention and specific cognitive tasks [71].

Many studies illustrates the functional significance of DMN suppression deficits in severe mental illness [69]. The continuous activation of this system is therefore related to illness.

The building circuits of the DMN (which comprises the cortical midline structure, lateral parietal and temporal areas as well as the posterior cingulate cortex and the medial prefrontal cortex [69]) are linked with the limbic system and amygdala, and are the same involved in the response to stress, fear or anger and all related neuroendocrine products and effects [72] (Figure 1-B).

As we described earlier, some areas of the limbic system within the DMN, receive afferents cardiac fibers which run through the vagus nerve $[73,74,75-79]$. This is the anatomical basis of the so called "neurovisceral integration model" of emotion regulation [75]. According to this model, verified by Thayer et al. since 2000 [80], the heart plays a central role in cognitive [81], perceptual $[82,83]$ and emotional $[74,84,85]$ functions, actively regulating neuronal activity and brain responses.

The default mode of humans appears to be that of mind-wandering, which correlates with unhappiness, fear and neuroendocrine production in the stress axis, with the activation of brain network areas associated with self-referential processing. The default-mode functioning of the brain continues to compare past experiences with anxiety and fear for the future, fearing that what made us suffer and could make us suffer will not occur [86], sowing the seeds of future CVD, as depicted in Figure 2 (please see "allostatic load", below).

Conversely, a task positive network has been associated with various attentional, present moment, and task-related processes, and is active during rest in an anticorrelated manner with the DMN $[87,88,89]$. This large task-positive network can be subdivided in distinct subnetworks, in particular the salience and executive networks [90].

The salience network is thought to be involved in the immediate, present moment processing or detection of relevant stimuli, and involves the dorsal anterior cingulate cortex and bilateral anterior insula [90,91]. The executive network, also referred to as the frontoparietal attention network, consists of dorsolateral prefrontal cortex and posterolateral parietal regions, and is involved in controlling attentional resources to deal with immediate or future demands $[90,91]$.

As stated, psycho-physical stress exacerbates the pathogenesis and progression of cardiovascular diseases. Basic research indicates that the Transcendental Meditation technique produces acute and longitudinal reductions in sympathetic tone and stress reactivity through DMN downregulation, decreasing cardiovascular risk factors and all-cause morbidity and mortality [92].

Music appreciation modulates DMN activity too [93]. As described by Kay et al., patients suffering from Alzheimer's disease or temporal lobe epilepsy exhibit changes whithin the DMN circuit. In this context music is able to switch off neural firing, interrupting epilepsy [94,95].

The activation of the DMN and mind-wandering, could be either a quite conscious process, as in the case of depression, which independently from other CVD factors (and even alone) could lead to coronary artery calcification [41], or unconscious, because an inflammatory state or even what we eat could cause depression or, more in general, influence our mood and relative thoughts $[27,96,97]$. The study and future researches on CVD have bear in mind the PNEI connections and their constant and mutual influences, as a single, integrated system of interaction with the environment [72]. Many trials of psychotherapy aimed at preventing cardiovascular risk, failed [48] probably because it was ignored the prospect of PNEI network. From this point of view, in fact, is not possible to treat depression with psychological-cognitive-behavioral therapies without trying to solve any underlying inflammatory or endocrine organic problem, which continues to fuel it.

However, it is possible to act on different fronts of the PNEI network, improving the health status of patients (with meditation, listening to particular kinds of music, with moderate physical activity, nutrition, herbal medicine and attention to social and physical environment in addition to standard therapies) [98].

\section{CFR is reduced in most of CVD}

Endothelial function is the backbone of cardiac functioning, so much so that its dysfunction is described in all cardiovascular diseases. In fact, it could be detected an endothelial function dysregulation in case of arteriosclerotic/ischemic disease [99], valvular disease [100] (aortic stenosis [101-107], mitral valve disease [108-110], mitral valve prolapse [111]), atrial fibrillation (in this case atrial endothelial impairment causes thrombogenesis through TLR-4 signalling) [112], ventricular tachycardia [113], ventricular septal defect [114] and cyanotic congenital heart disease [115], left apical ballooning 


\section{Efferent Pathway Afferent Pathway}

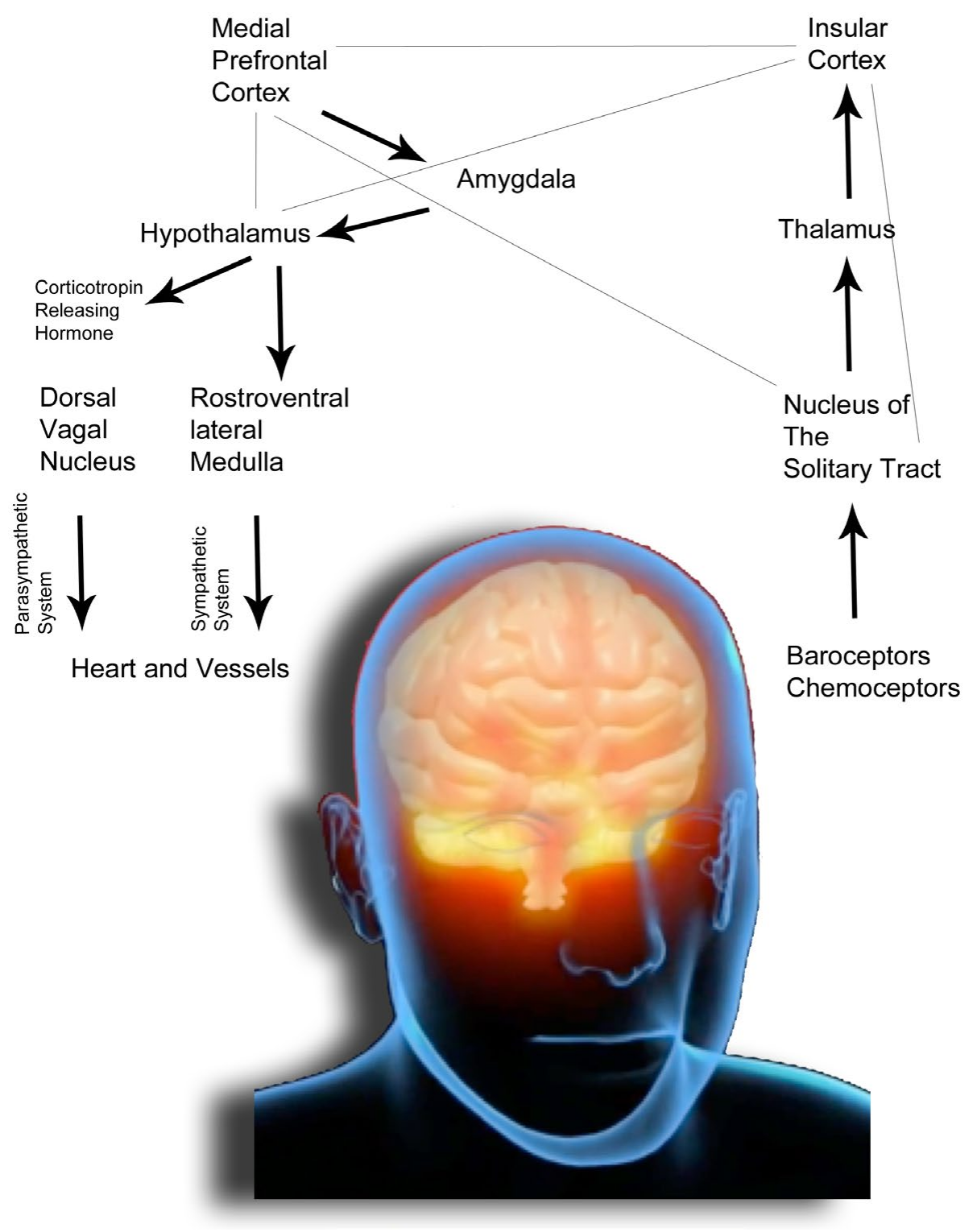

Figure 1A. The drawing schematically represents the anatomical organization of the autonomous nervous system in humans. The Default Mode Network comprises cortical areas (the cortical midline structure, lateral, parietal and temporal areas, the posterior cingulate cortex and the medial prefrontal cortex) connected to the amygdala and limbic system. Heart and vessels function is finely adjusted through parasympathetic and sympathetic neural stimulations and hypothalamic hormones which constitute the efferent pathways of the system (for simplicity we quote only corticotropin releasing hormone, which mediates the release of cortisol, the main stress hormone).

syndrome [116], dilated cardiomyopathy $[117,118,119,120]$ and heart trasplantation $[121,118,122]$.

As previously stated, this parameter is therefore of paramount importance from a prognostic point of view as well as able to predict the onset of a cardiovascular disease [123].

\section{Stress leads to endothelial dysfunction}

All the factors that come into play in the stress reaction determine a endothelial dysfunction $[124,125,126]$. From the point of view of PNEI network it is easy to see how even the only mental stress can cause an alteration of endothelial function in the coronary district [127,128-132], and beyond [133], that is transient [134] or persistent [135] depending on the duration and severity of mental stress [136]. Furthermore, it is interesting to notice that higher levels of both cognitive and somatic depressive symptoms are associated with a higher propensity to develop myocardial ischemia with mental stress, but not with physical (exercise or pharmacological) stress [137]. 


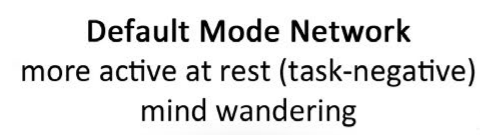

Default Mode Network mind wandering

\author{
Attention Network \\ more active during tasks (task-positive) \\ engaged attention
}

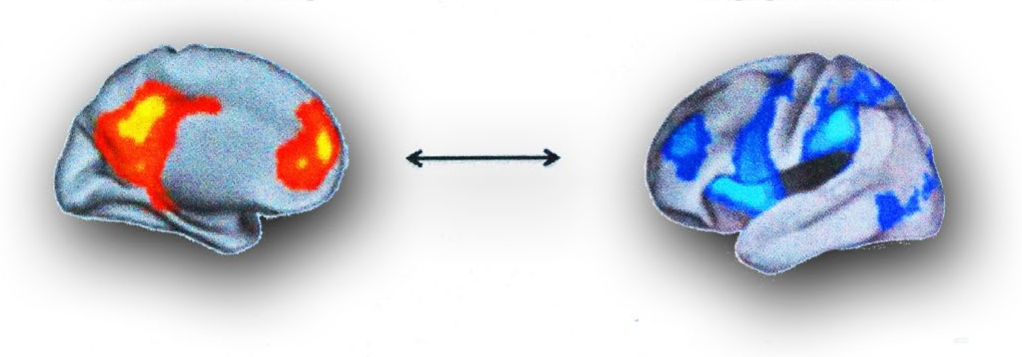

MIND WANDERING

FOCUS

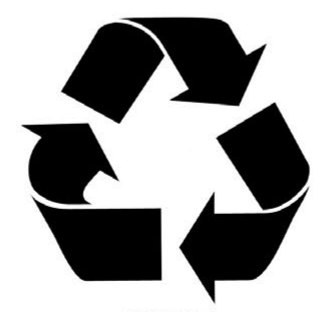

AWARENESS

SHIFT

Figure 1B. Top. Brain networks associated with mind wandering and attention. The brain can be divided into two-large scale distributed network: the default mode network, in which is associated mind-wandering activity, and the attention network that is associated with focused states demanding attentional resourses. Down. The process of attention during meditation. A theoretical model of dynamic cognitive states experienced by a non-expert practioner during a session of meditation. When attempting to sustain focus (FOCUS) on an object (breathing, mantra, images,etc.), an individual inevitably loses this focus and experiences wandering of attention (MIND WANDERING). At some time during mind wandering, the practitioner becomes aware that his/her mind is not on the object (AWARENESS), at which point he/she disengages from current train of thought and shifts attention back to the object (SHIFT), where it stays focused again for some period of time (FOCUS). Whith practice, the time spent during the focused and conscious thought increases. There are various methods of meditation with a common experiential goal. It's like climbing a mountain: there are several trails, slopes, ascent velocities and path lengths, but the summit is the same. Modified from Schmidt et al. [91].

\section{The allostatic load and the programmimg of CVD}

After this long introduction, necessary to understand the game of influences acting in every moment of our lives on the endothelium, we can connect into a single mechanism all these details (Figure 2). This overview will allow us to clarify and suggest what can be done in terms of prevention and treatment of cardiovascular disorders, as well as what type of research is needed for this purpose.

Every human being is born inheriting from their parents not only the genetic makeup, but also how to express it. In particular, we born with a precise stress-axis programming [138,139-142]. As described by Harris et al. "an adverse foetal environment is associated with increased risk of cardiovascular, metabolic, neuroendocrine and psychological disorders in adulthood. Exposure to stress and its neuroendocrine and immune mediators may underpin this association. In humans and in animal models, prenatal stress, excess exogenous glucocorticoids or inhibition of 11 $\beta$-hydroxysteroid dehydrogenase type 2 (HSD2; the placental barrier to maternal glucocorticoids) reduces birth weight and causes hyperglycemia, hypertension, increased HPA axis reactivity, and increased anxiety-related behaviour. Molecular mechanisms that underlie the "developmental programming" effects of excess glucocorticoids/prenatal stress include epigenetic changes in target gene promoters. In the case of the intracellular glucocorticoid receptor (GR), this alters tissue-specific GR expression levels, which has persistent and profound effects on glucocorticoid signalling in certain tissues (e.g. brain, liver, and adipose). Crucially, changes in gene expression persist long after the initial challenge, predisposing the individual to disease in later life. Intriguingly, the effects of a challenged pregnancy appear to be transmitted possibly to one or two subsequent generations, suggesting that these epigenetic effects persist [141]".

Thus, each individual is already born inheriting some resistance or vulnerability to stress: in practice, this means that some people are inclined to consider something as a danger or as a threat, and will have a greater tendency to be worried about the future, to get angry or feel guilty [143]. Then, on this ground, will act on the course of life, being able to change the situation for better or for worse. We already cited that the epigenetic signatures are stable but reversible. Despite the "stress thermostat" is already programmed in the course of intrauterine life, it can be further modified by each individual in a lifetime. Obviously they will experience acute and chronic stress of various kinds, physical or psychosocial, constantly activating DMN circuits and the stress axis.

From the point of view of the PNEI-network and of the stress system, we have to change the concept of "homeostasis" to "allostasis". Over 60 years ago, Selye recognized the paradox that the physiologic systems activated by stress can not only protect and restore but also damage the body [144]. The long-term effect of the physiologic response to stress is called "allostatic load" [145]. "Allostasis" - the ability to achieve stability through change- is critical to survival [144]. In fact, after a solicitation of any kind, our PNEI-system adapts learning and changing its functions being more responsive in the event of recurrence of a stimulus of the same type. Is the case of the nervous 


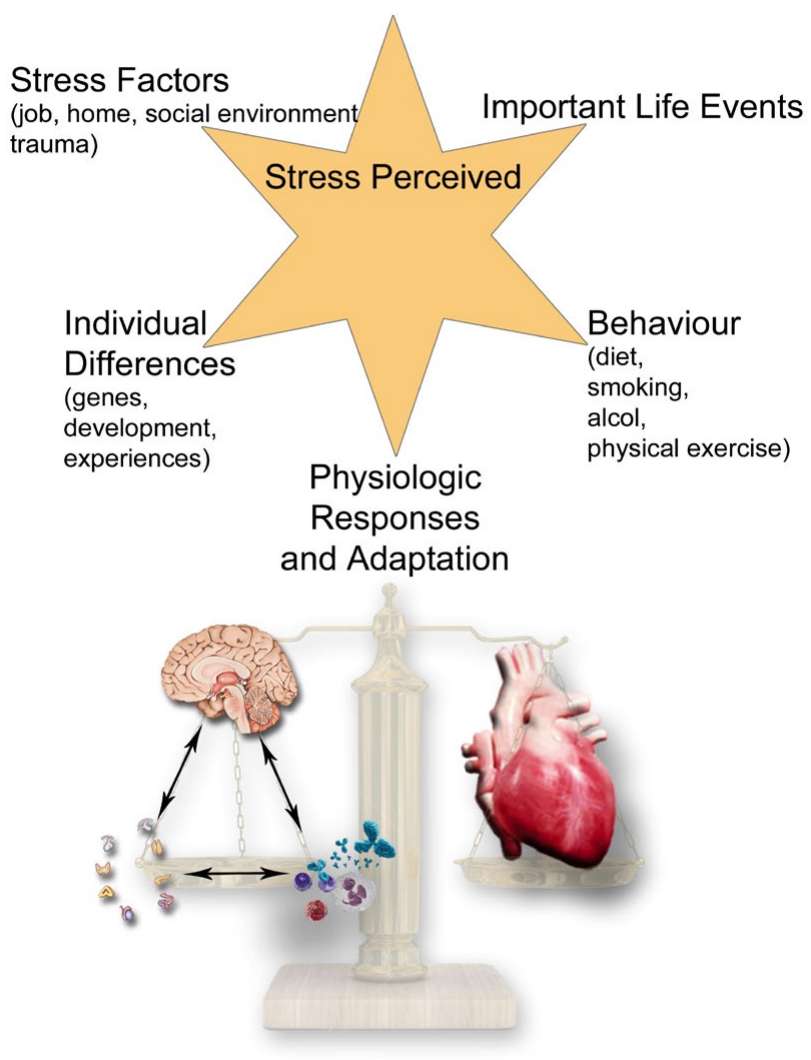

\section{Allostatic Load and cardiovascular health}

Figure 2. The allostatic load and the chronic building of CVD.The picture painted shows that the body is able to respond adaptively to the adverse circumstances that threaten its integrity through activation of the sympathetic-adrenergic and the HPA systems. The stress response, which Selye called "general adaptation syndrome" or GAS, consists of a stereotyped sequence of three distinct phases: an alarm phase where the coordinated action of neurotransmitters and hormones promotes the rapid mobilization of energy resources available to face the stressor; a phase of resistance, in which the body's response reaches a stable equilibrium and the manifestations typical of the alarm phase disappear, to reappear in the final stage of exhaustion, in the case the stimulus persists and physiological resources are depleated. A stressor can be anything that can evoke GAS whether physical (trauma, thermal injury, infection and poisoning) or psychological. Although essentially non-specific, the GAS can be realized in a variety of polymorphic biological responses depending on the nature, location and extent of the damage induced by various stressors and based on the individual's genetic and epigenetic background. In fact, the activation way of the stress axis can be epigenetically inherited from parents and over the generations. The GAS may represent a pathophysiological basis common to many diseases and biological processes apparently unrelated. "Adaptation" and "damage", in any organ, are two sides of the same coin: the stress phenomenon and its network.

In truth, since the 70s of the last century, Mason et al. [463] shifted the focus on the interactions between stressful stimuli and psychological homeostasis, criticizing the concept of the non-specificity of the stress response, documenting how the typical elements of GAS undergo significant changes depending on the context, history and personal characteristics of the individual. Mason notes that when removing the psychological concomitants of anxiety associated with the stressor, disappears also the GAS reaction: the psyche overlaps and is connected to the "biological machine" in the regulation of body functions. A few years later, in 1988, Sterling and Eyer [464] propose, for the first time, the concept of "allostasis". They observe that in response to environmental stress, physiological parameters are changed in line with the behavioral states, which, in turn, correspond to specific states of brain activity. The sensory input from any form of stressors, physical or psychological, are firstly processed by the brain to influence any kind of physiological response and these inputs can be changed from the expectations and individual evaluation processes [465]. Subsequently, Chrousos, Goldstein [466,467] and Sapolski [468] described as a physiological system disrupted by a stressor responds "learning" by the event itself and readjusting its operating parameters around new reference set-points (allostatic accommodation). The body under stress does not bother to return to its "normal" values of balance, but sets in motion a new balance, evolutionarily advantageous, able to put him in the best possible condition to face an environmental danger, real or imagined that is.

A common example: the blood pressure rise during the day according to the activities that take place and the state of individual alert. Endocrine and cardiovascular systems anticipate future needs, to respond to a possible sudden request. Obviously, the anticipation also involves psychological states of anxiety, apprehension, concern and regulation of molecules as cortisol and adrenaline [469]. It's the brain that evaluates and decides whether a particular situation merits a state of alert; psycho-cognitive functions, such as anticipation, risk assessment, coping strategies, memory, are integrated in the processes of physiological regulation [470]. But stress load management has a cost, called "allostatic load". Under repeated stress, the physiological changes become less "elastic" and more and more difficult to reverse; are adaptive and healthy responses in the short term [471], that may have negative consequences in the long term [472]. From this perspective, there is nothing "broken" or "sick" in the molecular PNEI regulation mechanisms, nor are present aberrations of cellular signaling pathways: simply, the brain, persistently alerted by environmental stimuli that considers as threats, performs nothing more than his job, keeping the physiological parameters at the set-point that believes (and has learned through experience) most suitable to deal with a threat, real or perceived that is $[473,474]$.

Going back to the blood pressure example: over time a thickening of the muscle layer of the arterioles occurs and even if we restore a state of maximum relaxation, blood pressure does not return to values of "normality" because of the need to push blood against an increased resistance (with potentially very harmful long term consequences on heart and vessels). Of course, the allostatic burden can show different aspects: can be linked to the excessive production of mediators of stress, some of which are toxic at high concentrations (the chronic presence of excessive levels of cortisol damages the hippocampus neurons and inhibits neurogenesis, hindering neuroplasticity, learning, memory and future further adaptations [475-478]); immune suppression can occur, with greater tendency to infections or predisposition to cancer $[479,480]$. The concept of allostatic load makes us see how fundamental our behavior and our way of life are to maintain health. As we will see, our behaviors obviously affect health, some positively, as a good sleep, a proper and prudent diet or moderate physical exercise and other negatively as smoking, the use of alcohol or drugs. The individual behavior can in turn increase or decrease the allostatic load, modulating the network of molecular PNEI relations.

Mental or physical stress lead to PNEI and epigenetic alterations with significant consequences, chronically or acutely. Another example concerns the modulation of endothelial function as a prelude to many CVD. 
plasticity and learning process [146-149], for the immune system following an infection, a mental stress or exercise $[150,151,152]$ and so on. Thus, after any experience that changes the PNEI network, it does not return to the origin point ("homeostasis") but always to another balance ("allostasis"). This process have been studied scientifically by McEwen et al.: "the mind involves the whole body and two-way communication between the brain and the cardiovascular, immune, and other systems via neural and endocrine mechanisms. Stress is a condition of the mind-body interaction, and a factor in the expression of disease that differs among individuals. It is not just the dramatic stressful events that exact their toll, but rather the many events of daily life that elevate and sustain activities of physiological systems and cause sleep deprivation, overeating, and other health-damaging behaviors, producing the feeling of being "stressed out." Over time, this results in wear and tear on the body which is called "allostatic load," and it reflects not only the impact of life experiences but also of genetic load, individual lifestyle habits reflecting items such as diet, exercise, and substance abuse, and developmental experiences that set life-long patterns of behavior and physiological reactivity. Hormones associated with stress and allostatic load protect the body in the short run and promote adaptation by the process known as allostasis, but in the long run allostatic load causes changes in the body that can lead to disease. The brain is the key organ of stress, allostasis, and allostatic load, because it determines what is threatening and therefore stressful, and also determines the physiological and behavioral responses [153]. Brain regions such as the hippocampus, amygdala, and prefrontal cortex respond to acute and chronic stress by undergoing structural remodeling, which alters behavioral and physiological responses [154]. Translational studies in humans with structural and functional imaging reveal smaller hippocampal volume in stress-related conditions, such as mild cognitive impairment in aging and prolonged major depressive illness, as well as in individuals with low self-esteem. Alterations in amygdala and prefrontal cortex are also reported. Besides pharmaceuticals, approaches to alleviate chronic stress and reduce allostatic load and the incidence of diseases of modern life include lifestyle change, and policies of government and business that would improve the ability of individuals to reduce their own chronic stress burden" [145].

This is important not only for every single person, because we have already seen that allostatic load will pass from generation to generation, through epigenetic markings.

This process makes clear the inheritance of cardiovascular diseases, such as combination of genetic stress expression programming/ vulnerability to stress and environmental factors. And is easily understand the mechanism by which the populations of immigrants from suburban areas or from the countries of the southern hemisphere, with lower cardiovascular risk [155,156], acquire the same or even higher cardiovascular risk of the territory in which they arrive [157,158].

The stress response involves three stages: an alarm phase, a phase of resistance and the final stage of exhaustion [159]. By this concept and the concept of allostatic load, it follows that the process leading to what we call "disease" is something slow, chronic, often not symptomatic, which provides a remarkable ability to compensation by the body, until exhaustion and the onset of acute symptoms or severe and life-threatening conditions. A typical example is the case of endothelial function. We have seen that endothelial cells are the target of hundreds of molecules that are activated under stress. The condition of chronic endothelial stress triggers the process of atherosclerosis until myocardial infarction [160].

\section{The long lag phase and compensation. What happens in the single cell under stress? The universal cell reaction}

Heart rate and cardiac output vary in response to the needs of the body's cells for oxygen and nutrients under varying physical and psychologic conditions. In order to respond rapidly to the changing requirements of the body's tissues, the heart rate, contractility and perfusion are regulated mainly by the nervous system, hormones, immune and intrinsic factors [161].

Let's see what happens in a single cell in a condition of stress (Figure 3). We present below only some key mechanisms. Our goal is not to go into the very complicated genetic and intracellular signaling pathways, but is to understand some of the principles of cell's behavior under stress. Different cells then, may present slightly different behaviors depending on their type and the organ to which they belong, but these mechanisms are fairly shared.

The body is made of cells and the same comments that we made for the macroorganism are shared by the cellular world. The "universal cell reaction", a coordinated biphasic response to external (noxious and other) stimuli observed in all living cells, was described by Nasonov and his colleagues in the mid-20 $0^{\text {th }}$ century [162]. Even at cellular level, after a stress, a phase of alarm follows, an adaptation stage and exhaustion through apoptosis or cell death in the event of continuous overload condition. Cells typically respond quickly to stress, altering their metabolism to compensate [163]. Various signals from the outside, often converge on same intracellular effectors making an intricate modulation game of cellular response. An interesting example of this concept, as yet largely unknown, is represented by the proteins Shc (Src homology and collagen omology) whose action spans several systems including the intracellular cascade of many $G$ protein-coupled receptors and tyrosine kinases receptors such as Ras/MPKP (mitogen activated protein kinase) and IP3 (phpsphatydilinositol 3-kinase)/Akt, integrins and cytosolic kinases, cytokines [164]. Shc proteins play a key role in the cellular response to stress [164]. A cell will tend to activate and optimize all metabolic processes designed to mantain or even maximize the production of energy [165] (for example, through Sir2alpha-p53 axis) [166]; will seek to maintain its own shape, dimensions $[167,168]$ and polarity (through LKB1-AMPK signalling system) [169]; the stress sensors protein kinase RNA-like endoplasmatic reticulum kinase (PERK), inositol-requiring protein $1 \alpha$ (IRE1 $\alpha$ ) and activating transcription factor 6 (ATF6) stimulate a homeostatic signalling network called "unfolded protein response" (UPR) that orchestrates the endoplasmatic reticulum's function in order to preserve cell function or at least its integrity in case of excessive stress [170-172]; moreover, the stressed cell regulates the processes of DNA transcription and replication by inhibiting the synthesis of proteins unecessary to overcome the acute event, saving energy and diverting its inherent resources in those activities aimed at promoting the survival of the cell [173] (heat shock proteins' (Hsp) response, UPR response, DNA damge response, PPAR etc [174-176]). If the stress stimulus persists, the cell switches from prosurvival signaling to signaling systems that will lead to apoptosis or death $[177,178]$. Stress modulates the rate of cellular aging. Epel et al. provided the evidence that psychological stress--both perceived stress and chronicity of stress--is significantly associated with higher oxidative stress, lower telomerase activity, and shorter telomere length, which are known determinants of cell senescence, promoting earlier onset of age-related diseases [179]. Furthermore, mitochondria contribute to immune activation following cellular damage and stress, generating reactive oxygen species (ROS) $[180,181]$. In normal conditions, the oxygen radicals produced by the 


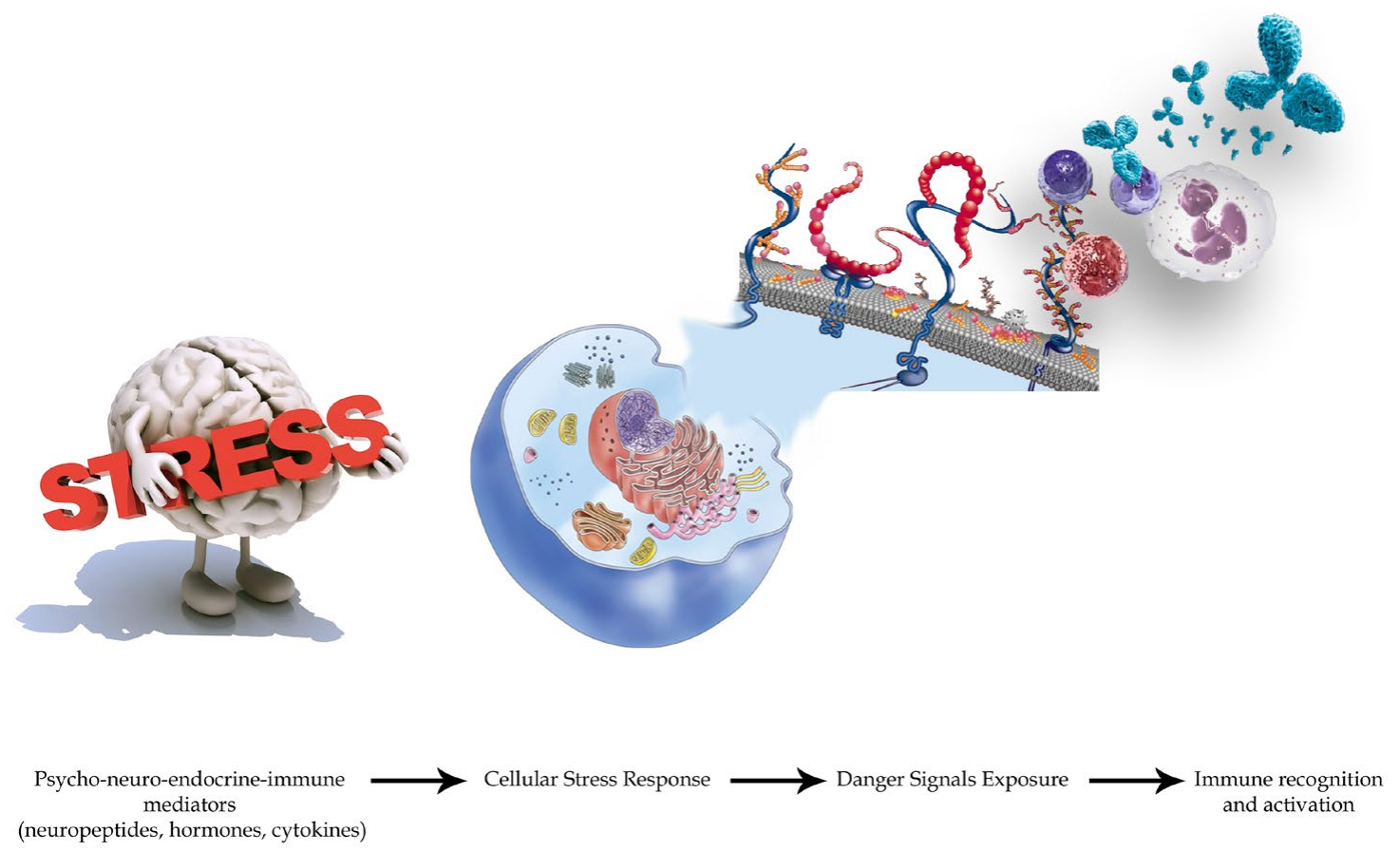

Figure 3. Psychological stress alone is able to trigger oxidative stress and the universal Cellular Danger Response (CDR).Moreover, in the CDR context, an extracellular matrix remodeling happens with the exposure of certain "danger-proteins" (danger associated molecular patterns or "DAMPS", matrix metalloproteinases or "MMPs" and high mobility box 1 or HMGB1) and fibrosis that can boost further the immune response. Furthermore, pro-angiogenetic substances are secreted with the goal of recruiting more energetic resources. All these phenomena involve epigenetic modifications by the action of circulating micro RNAs. We want to focus on the importance of the neuro-endocrine-immunitary impact of chronic stress (physical and mental) for health and cardiovascular balance. In particular, among the mechanisms described, we want to emphasize as a situation of prolonged psychological stress is inscribed in the extracellular matrix through some major mediators such as beta2 adrenergic receptors-protein kinase A, vascular endothelial growth factor (VEGF), MMP-2 and 9, S100A1-9, DAMPs (heat shock protein-72, HMGB1, proteins RAE-1 and Mult1). These elements are the "warning signs" recognized by the immune system (through TLR-4 pathway). Studies performed on biological tissue scaffolds by Daly et al., demonstrated that these elements are able, alone, to evoke an inflammatory response when implanted in vivo [481]. All these aspects take on very intriguing contours and nuances if we consider the evidences that link in a double-locked way the psychological/emotional profile of a subject with the phenomenon of inflammation and harmful effects, with tissue damage, at cardiac level [482].

mitochondrial metabolism are critical to modulate a number of kinases and phosphatases, redox sensitive transcription factors and genes $[182,183]$. In this context the NO plays a central role [184]. Under conditions of stress, and continuous demand for energy surplus [185], ROS could become excessive, creating a toxic environment within the cell (ROS damage mitochondria, cell membranes, DNA, proteins, and lipids), that will affect its survivor [186]. Naviaux et al. demonstrated that ROS and chronic oxidative changes in membrane lipids and proteins found in many chronic diseases are not the result of accidental damage but are the result of a highly evolved, stereotyped, and proteincatalyzed "oxidative shielding" response that all eukaryotes adopt when placed in a chemically or microbially hostile environment [187]. Thus, ROS production and the condition of "oxidative stress" is the response to a chronic metabolic condition of stress acting on a cell, not the cause $[187,188]$.

The continuous functional cellular overload [185,189], is signaled to the immune system, which in turn will be constantly activated, creating a condition of low-grade chronic inflammation [190].

A new paradigm in immunology reveals that the driving force for the immune system is the need to recognize danger, not only "self" or "non-self". The model starts with the idea that the immune system defines "danger" as anything that causes tissue stress or destruction. In this model, antigen-presenting cells are activated by alarm signals from stressed or damaged tissues. Without this activation, no primary immune response can occur [191]. As a matter of fact, Gallucci et al. demonstrated that dendritic cells, the most potent antigen-presenting cells, need to be activated before they can function to initiate an immune response. In the absence of foreign substances, dendritic cells can be activated by endogenous signals received from cells that are stressed, virally infected or killed necrotically, but not by healthy cells or those dying apoptotically [192].

In this way, during the cellular response to stress (cell danger response (CDR), the cell continues to signal to the immune system its dangerous condition, activating a sterile inflammation (or inflammasome [193,194]). The innate immune system can sense danger signals through different pathogen recognition receptors (PRR) such as TLR, nod-like receptors and receptors for advanced glycation endproducts and the activation of a PRR results in the production of cytokines and the recruitment of leukocytes to the site of injury [195].

After the danger has been eliminated or neutralized, a choreographed sequence of anti-inflammatory and regenerative pathways is activated to reverse the CDR and to heal [193]. When the CDR persists abnormally, whole body metabolism and the gut microbiome are disturbed [196], the collective performance of multiple organ systems is impaired, behavior is changed [197,198], and chronic disease results, through PNEI network activation (allostatic load) 
[199]. It is interesting to note that psychological stress alone is able to trigger the CDR [200].

Moreover, in the CDR context, an extracellular matrix remodeling happens [201-205] with the exposure of certain "danger-proteins" $[195,206]$ (danger associated molecular patterns or "DAMPS", matrix metalloproteinases or "MMPs" and high mobility box 1 or HMGB1) and fibrosis [195,206-214] that can boost further the immune response[215-218]. Furthermore, pro-angiogenetic substances are secreted with the goal of recruiting more energetic resources $[189,219$ 222]. All these phenomena involve epigenetic modifications by the action of circulating miRNAs [223]. Finally, it was recently discovered that a cells under stress strengthens their ties with neighboring cells through connections called "tunneling-nanotubes" or TNTs, through p53 activation [224]. TNTs represent a subset of F-actin-based transient tubular connections that allow direct communication even between distant cells [225]. These structures have been found in numerous cell types and shown to transfer electrical signals and cytosolic materials such as ions, nutrients, proteins, organelles, plasma membrane components and miRNAs [224-232]. This type of structures are also present in plant and animal cells [233]. It's wonderful to note that even the same stress response, both on the body and on the cellular level, it is similar to what happens in nature in the plant world. Even the plants in a forest make connections between them to respond to dangers [234236] . The Figure 4 shows the comparison with the plant world.
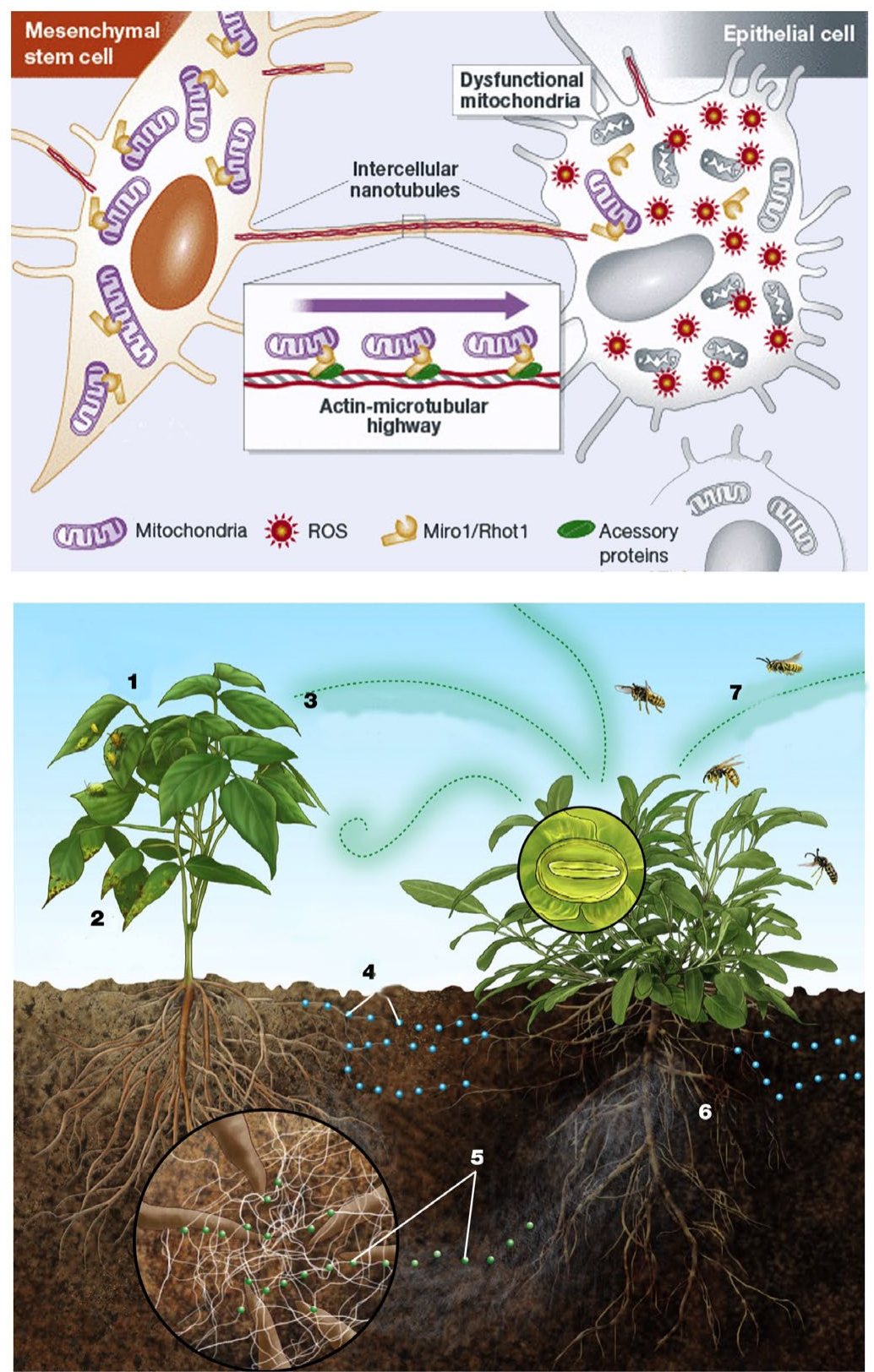

Figure 4. An endothelial cell in danger (under stress) reports its condition to the surrounding cells secreting various substances (see main text), and creating connections with them, called tunneling-nanotubes (TNT).Similarly, when insects or viruses attack a plant (1 and 2), the plants attacked emit signals in the air (3) and in the soil (4). These latter signals, passing through a network of fungi that connects the roots of the plants between them (5), alert neighboring plants, that, in turn, attract predators of insects that are attacking the plant in difficulty (7). Modified from [483] and [484]. 
In conclusion, it is currently understood that the cellular stress response is a hallmark of many common human diseases: firstly, because the stress stimulus may be too strong and/or prolonged, thereby allowing insufficient time for recovery to the normal status and secondly, a stressed cell's ability to handle even physiological levels of stress load may be altered in disease states, similarly resulting in detrimental outcomes [174]. An understanding of the CDR permits us to reframe old concepts of pathogenesis for a broad array of chronic, developmental, autoimmune, and degenerative disorders (including autism spectrum disorders, attention deficit hyperactivity disorder, asthma, atopy, gluten and many other food and chemical sensitivity syndromes, emphysema, Tourette's syndrome, bipolar disorder, schizophrenia, post-traumatic stress disorder, chronic traumatic encephalopathy, traumatic brain injury, epilepsy, suicidal ideation, organ transplant biology, diabetes, kidney, liver, and heart disease, cancer, Alzheimer and Parkinson disease, and autoimmune disorders like lupus, rheumatoid arthritis, multiple sclerosis, and primary sclerosing cholangitis) $[199,237]$.

Exposure to stressful stimuli, such as psychological stress, activates HPA axis inducing cellular oxidative stress [238-240]. As the doctrine of the PNEI network teaches, all physiologic processes are doublelocked: for example depression causes oxidative stress and it is even true that the condition of oxidative stress can cause depression [30,241].

The activation mode and the extent of neuroendocrine responses depends on the type of stimulus and can, as we have seen, be partly inherited [138,242,243]. The stress response is non-specific and unambiguous both in body and in individual cells that compose it.

It's easy to understand how the continuous action of a physical stress, by acting continuously on a point or on a specific organ of our body, can determine, over time, its dysfunction linked to the processes described up to here. The future challenge will be to understand how, in the same way, each type of mental stresses are written into our bodies, maybe hitting particular organs; or how, after determining a generalized response, lead to the onset of organ dysfunction and symptoms, simply in the more "epigenetically vulnerable" district.

\section{The atomic world: life is a symphony of oscillatory patterns}

\section{Biological rythms}

All life on Earth is based on the alternation of cyclical phenomena, which can describe a precise rhythm, a definite oscillation/vibration. There is a day/night cycle, the seasons, solar/moon cycles, heart beats and breathing activity, the oscillation of the electro-magnetic fields and atoms. All observable phenomena encompass a symphony of precise rhythms. Many human biological responses are orchestrated and integrated within these cycles [244], and many of the behaviors and physiology of the animals and humans are related to the lunar phases [245]. Human society is structured around the lunar rhythm $[246,247]$, even playing its influence regardless of our awareness of the current moon phase [248]. All our lives contain an infinite number of rhythms, with vibrations that move from atomic to molecular floor and biochemical metabolic reactions. Fluctuations in our brain activity, heart and respiratory rates correlate with our emotions, thoughts and our psycho-spiritual attitude [249,250]. Many common diseases in humans (such as cancer, heart disease, diabetes mellitus or psychiatric disorders, such as depression) seem to be linked to disruptions of circadian cycles and to clock genes variation [251]. In this way, rhythms communicate bioinformation that governs a wide variety of functions, including guiding that of living beings towards health and well-being [252]. In fact, pulsatile dynamics provide critical capabilities to cells in stress response, signaling, and development [253].

All living processes are based on the timing of a myriad of rhythmic phenomena and the brain plays a key role in directing this symphony. It has been seen that the central nervous system acts as a center of fusion and integration of different cellular and subcellular oscillatory signals. For example, it has been shown that the regulation of metabolism and energy production of the entire organism across the daily cycles of fasting and feeding is orchestrated by subcellular transcriptional oscillations (clocks) controlling the basic dynamics of substrate biosynthesis and energy production (adenosine triphosphate, ATP) at the mitochondria [254]. Then, let's think to the development of an embryo, the neuronal plasticity and to the phenomena connected with the memory process, to the differentiation of stem cells and the biological response to stress: everything is based on the rhythmic activation of genetic sequences called "clock genes" [251,255-257].

All the just mentioned processes, as well as the heart and vascular myocells' contraction, are regulated by the $\mathrm{Ca}^{2+}$ ion and there are processes able to adjust with precision its availability in the cytosol. In particular, it has recently been described cellular pacemakers sites generating subcellular $\mathrm{Ca}^{2+}$ waves and oscillations, to regulate the condition of myocellular contraction [258]. Nature choses to create subcellular clocks to guarantee an exquisite regulation of the $\mathrm{Ca}^{2+}$ dynamics essential for many processes.

In general, aberrant cellular oscillatory patterning is associated with severe diseases, ranging from primary ciliary dyskinesia (loss of molecular motors that power ciliary beating, abnormal lung development and function, infertility, situs inversus and severe heart malformations [259,260], to metabolic syndrome [261] or cognitive disorders [262].

Underlying all of the above reported findings one may see that the coupling of intrinsic oscillatory rhythms originating at the molecular and single cell level is intimately related to higher-level structure, function, and the generation of a wide range of biological rhythms [263]. At the cellular and subcellular levels, oscillatory behaviors have been shown to emerge as a direct result of simple negative feedback loops and coupled positive and negative feedback loops [264], and rhythms arise from stochastic, nonlinear biological mechanisms interacting with a fluctuating environment [265], indicating that oscillations are a natural outcome of a variety of essential cellular biochemical interactions. Another concept central to the study of biological rhythms is the existence of coupling between oscillators giving rise to collective behaviors such as phase synchronization [265]. For example, this is a modern key concept of the neural network functioning [266-268] and it's important to understand common synchronous cellular behaviors in spite of intrinsic parameter fluctuations and the presence of extrinsic noise [263] or the recently discovered "chimera states" in networks of coupled oscillators wherein a wide spectrum of complex states emerge from the underlying dynamics of a system of weakly coupled oscillators containing both synchronous and asynchronous elements [269]. Thus, the progression toward rhythmicity and complex behavior is a natural outcome of multipart, dynamically interlinked systems.

\section{Cell-cell communication and endogenous Electro Magnetic Fields (EMF)}

We are constantly immersed in both natural and human-made EMF. In particular, life on earth has evolved under the influence of its 
geomagnetism. The earth produces weak EMF of about 50 microTesla [263]. Nowadays, the effect of these constant magnetic currents of extremely low frequency (ELF) on biological systems and in particular in humans, have been clearly demonstrated [270,271]. In addition to a significant amount of literature on bioeffects due to geomagnetic-range field strengths, a growing body of evidence has shown that effects can also occur at much lower field strengths (on the order of nanoTesla) showing that the energies of interaction are substantially lower than the average random thermal energy due to Brownian motion [271], suggesting the existence of a more subtle level of bioinformation transduction operating at extremely low energies.

Muehsam et al. brilliantly summed up, in a recent review [263], many examples related to the biological and molecular effects of EMF and solar influence on the biological balance of the earth.

From what we have seen so far, each atom in our body is made and is embedded within an interconnected network of oscillatory elements. For example, adenosine receptors are being studying as molecular vibrating structures, communicating through fluctuations [272]. Every harmonic oscillators interact with one another creating living aggregates, cross-talking with each other and with the environment, transforming inner and outer stimuli into electromagnetic and chemical signals [273]. The inter-atomic synchronization, with resonating rhythms, determines their functional assembly into molecules, cells, tissues, organs, and entire individuals [274,275].

From this point of view, intercellular communication is critical for normal physyological processes, so much that we can consider diseases as simple changes in communication between cells [276], under the PNEI macro-system described. In fact, defects in cell-cell communication are associated with a wide variety of diseases, including diabetes, autoimmune disorders, atherosclerosis, cancer, neuropathy, and infertility, among others [277].

Due to the oscillatory nature of the elements that compose it, also the communication between the cells occurs by means of EMF which are able to activate of membrane proteins, and specifically proteins involved in signal transduction mechanisms [278].

Once again, a key example is related to $\mathrm{NO}$ and the influences it receives from EMF. According to Muehsam et al. [263]: "NO diffuses freely and rapidly across cell membranes, plays key roles in the rapid regulation of microcirculation, inflammation, and the cell growth and repair process [279], and has been demonstrated to regulate chromatin folding dynamics, and thus gene expression, in human endothelial cells[280]. The importance of transient NO signaling is underscored by the observation that Nature has evolved a remarkable sensitivity to subcellular, subsecond (100 ms) NO transients in the low picomolar range, as demonstrated in human embryonic kidney HEK 293 T cell lines [281]. A growing body of literature has demonstrated that NO signaling plays a significant role in biological EMF transduction, and effects on NO expression and NO-dependent pathways have been reported for a wide variety of nonthermal EMF amplitudes, frequencies, and signal shapes [282-289]. Thus, modulation of NO signaling has been established as one means by which cells and tissues can respond rapidly to changes in the EMF environment and could interact with nuclear DNA through modulation of chromosome folding dynamics [280]".

From what has been said so far, we can understand the recent alarming observations by Lancellotti et al, about the negative effects related to cardiac magnetic resonance that was found to be associated with minor but significant alterations or immediate blood cell activations figuring inflammatory response, as well as DNA damage in T lymphocytes [290].

\section{In summary: Physics crumbs to interpret a human being $[263,291]$}

Using the sight provided by Physics, the web of life can be seen as a complex system made of matter and the ultra-structure of matter can be understood in terms of harmonic oscillators, or tiny subparticles in constant vibration (please see the video: "Powers of ten () 1977 EAMES Office LLC, available at www.eamesoffice.com or at https://www. youtube.com/watch?v=0fKBhvDjuy0). All reality is quantum energy in terms of vibrations according to specific information (frequency, wave length, harmonics etc.).

These harmonic oscillators interact with one another creating living aggregates, cross-talking with each other and with the environment, transforming inner and outer stimuli into electromagnetic and chemical signals.

This signal transmission allows the dynamic balance of the living system with itself and with the surrounding environment. Intramatter dialogue occurs in terms of resonance (oscillating tendency), coherence (fixed relationship between the phase of interacting energy waves) and complexity. Simply stated, everything at a subatomic level is in dynamic oscillation and interacts with other oscillating elements. The system tends to assume an oscillating modality that is the sum of its components. It can be described by depicting its oscillation characteristics (frequency, wave length, energy etc.), its coherence (the relationship between the phase of its components) and according to its complexity (the number of elements that build it, its inner relationship, environmental influences and so on).

Brian Greene, professor of Physics at the Cornell and Columbia University is a proponent of the "superstring theory" with which science is describing the vibratory nature of creation. According to this theory, which unifies Einstein's theory of relativity with Planck's quantum mechanics, the microscopic world is full of tiny violin strings (long about a hundred billion of billion less than an atomic nucleus) which, according to their vibrational conformation, give rise to the different atomic structures (quarks, neutrinos, electrons etc.) [292]. At the microscopic level, the universe is a symphony of sounds that give rise to all matter [293].

Different works describe neural and genetic network activity from this point of view [294].

In other words, only particular proportions in the subparticles' oscillation pattern allow their tuning and their aggregation into atoms, molecules and more complex systems (Figure 5).

Thus, every single person could be depicted as a complex system of resonating matter in which some particular notes can be recognized, or some frequencies with which its atoms and the molecules of life are constantly assembled and renewed: (1) heart rhythm: $40-80$ beats per minute, $0.666-1.333 \mathrm{~Hz}$; (2) breathing: $15-24$ breaths per minute, $0.25-0.4 \mathrm{~Hz}$; (3) platelet lifetime: $7-10$ days, $1.66 \times 10-5-1.25 \times 10-7 \mathrm{~Hz}$; (4) oscillating frequencies of Sodium or Potassium ions: 43 and $47 \mathrm{~Hz}$; (5) brain waves: epsilon $0.5-1 \mathrm{~Hz}$, supradelta $1-2 \mathrm{~Hz}$, delta $2-4 \mathrm{~Hz}$, theta 4-8 Hz, alpha $8-16 \mathrm{~Hz}$, beta $16-32 \mathrm{~Hz}$, gamma $32-64 \mathrm{~Hz}$, supergamma 64-128 Hz [294].

The correct and healthy function of our body, from an atomic point of view, seems to be like a big, harmonic musical symphony with particular proportions and relationships (and we currently handle it 


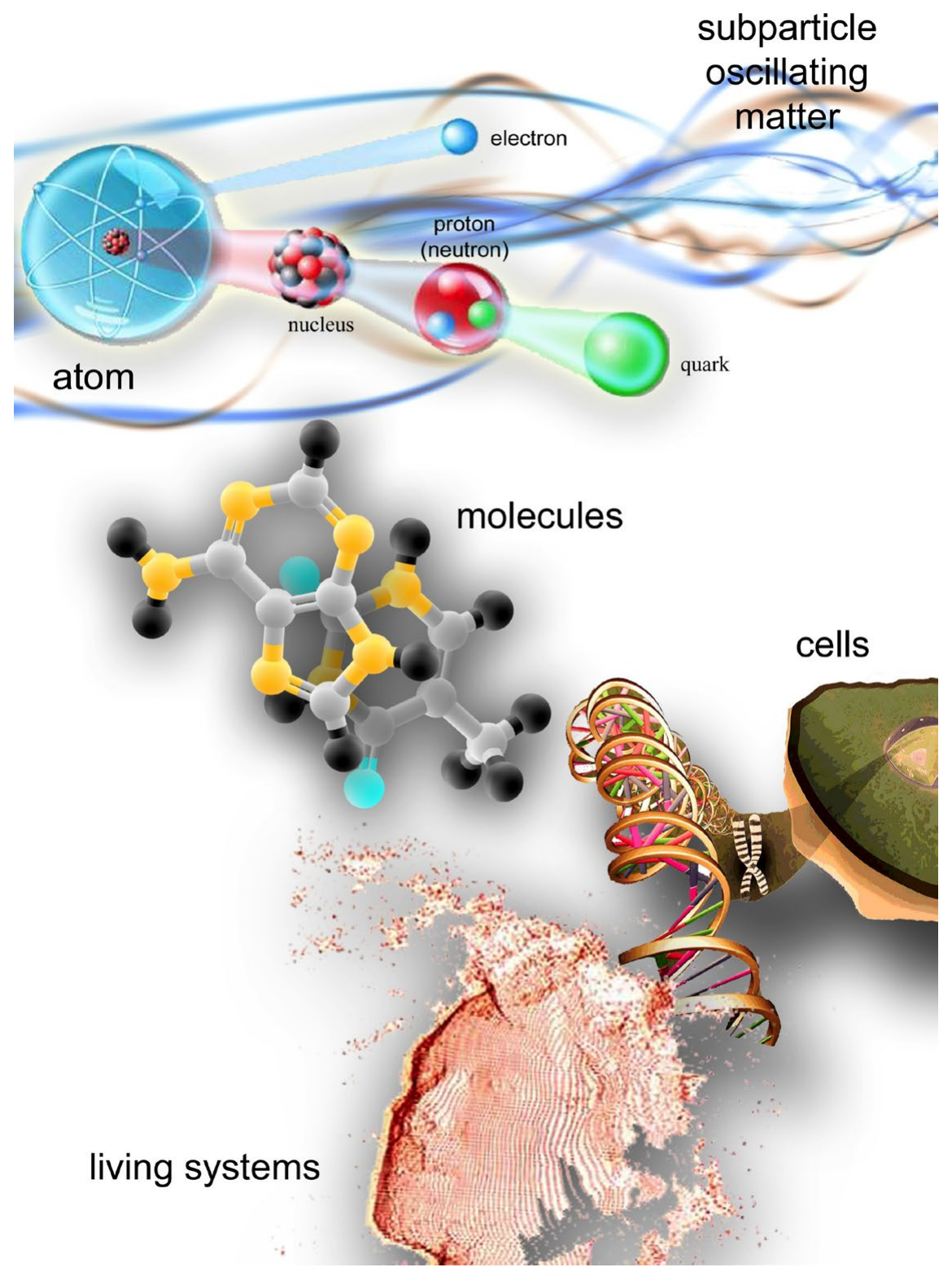

Figure 5. Matter is composed by oscillating elements. The oscillation pattern of subparticles allows them to tune and aggregate into atoms, then into molecules, cells, tissues and more complex living systems. From this point of view, we are vibration, we are like music. We can speculate that music, composed with certain proportions between notes, interacting with subatomic matter, makes up the harmony in its swing, restoring a "healthy balance" at macroscopic level. The effects of music on health are independent from the type of music and from the subject's taste. It is also conceivable that the same happens with thoughts and feelings, which may correspond to different oscillatory patterns at subatomic level. We constantly vibrate according to love or according to fear, influencing our surroundings and being affected by them. As the saying goes: "as we love ourselves we love others and our surroundings".

with our diagnostic tools, such as magnetic resonance imaging, X-ray methods or ultrasounds).

The need for new theoretical models and new perspectives in medicine and life sciences, in order to understand and cure the human being

In our long journey in the understanding of endothelial function we dug deep, from the plane of the human being understood as a macrocosm of PNEI-connections, down to the cellular, the molecular and atomic floor. The whole structure of reality is an interconnected network of elements, in constant dialogue. The example of the endothelial function and its determinants, emphasizes the need for new theoretical models and new perspectives in order to understand and cure the human being.

The need to reduce the distance between medicine and its theoretical foundation: the physics

Contemporary physics, thanks to the theory of relativity and quantum mechanics, is flocking to the study of systems far from the equilibrium concept and to the study of the laws of chaos. This 
approach puts in crisis the Western medical model, which is still based on the mechanistic Newtonian paradigm. Instead of a linear view of reality, based on the cause-effect relationship, it emerges a circular structure, where each element is always in relation to the complexity: each element affects and is affected by the complexity that surrounds it [295]. It's clear that this new scientific perspective hits a biomedical model based on a mechanistic and reductionist vision of human pathophysiology and based on a sectorialized and hyper-specialistic clinical point of view.

Since the early days of quantum physics, its influence on biology has always been present in a reductionist sense: quantum physics and electrodynamics shape all molecules and thus determine molecular recognition, the workings of proteins, and DNA [296]. Also van derWaals forces, discrete molecular orbitals, and the stability of matter: all this is quantum physics and a natural basis for life and everything we see [297].

As West pointed out [298], "as scientists we measure things; the position of stars in the sky, the sounds of the stars [299], the amount of rainfall in a region over the year, the precise pathway of water movement from the soil through the plant roots [300], tidal networks [301,302], or the number of heart beats per minute of a patient in our care. These numbers tell us about the phenomena we want to understand. An astronomer deduces whether the faint dot over head is a fixed star, a moving planet or a rocketing comet using the physical theories of cosmology. The numbers tell the meteorologist if there is a pattern of increasing or decreasing rainfall and whether that pattern indicates an organized change in the weather. A physician determines whether the pattern in the heart beats reveals if the patient has a cardiovascular problem that requires intervention or s/he is having an anxiety attack. Each science organizes measurements in ways that communicate the most to the practitioner and taken as a group they constitute the scientific view of the world, which is to say that if it is a matter of science it can be measured. In keeping with the data-based perspective, the measurements in and theories of molecular biology and genetics in the latter half of the twentieth century produced a shift in medical outlook from the pathologies of the cardiovascular, respiratory and motor control networks to the influence of molecules on health and well being. However, in the past decade or so the pendulum has begun to swing back from the concentration on individual molecules to a focus on the properties of networks of molecules and a determination of the emergent properties of such complex interactive networks. This is particularly true in physiological networks, which exhibit complex, non-stationary, intermittent, scale-invariant and non-linear [303] behavior [304]". New mathematical models are then emerging to explain the matter and pathophysiological phenomena. The complexity and interdependence of reality put in check the concept of linear cause and effect.

A system is a collection of interacting elements. Behavior of the system is distinct from the behavior of its parts or elements. These elements interact with each other directly and indirectly to modulate the system function. The reductionist or mechanistic view of nature involves reducing systems into their component parts (elements) in an attempt to understand them [305]. This is the basis of linear system analysis, where output is proportional to or can be determined through applying simple differential equations to the input. Yet systems within nature, including the human body, frequently lack mechanical periodicity or linear dynamics and thus are referred to as nonlinear systems [306]. Within nonlinear systems, output is usually not proportional to input, and output for the same input value may not be constant over time [307]. Furthermore, in contrast to linear systems, breaking a nonlinear system down into its elements (parts) and analyzing those parts under controlled conditions does not accurately reflect the complex behavior present, nor capture the dynamic relationships operating between various elements [308,309].

The so-called "network effect" (and endothelial function is a good example of this) is being investigated through the fractal statistics [298], chaos theory [310-314], systems biology [315-319], Heisenberg S-Matrix and Feynman Diagrams [320], Nash equilibria [321-326], Steiner trees $[327,328]$, distribution-free approach to constructing the confidence region of multiple parameters [329].

The approach to construct confidence intervals for the study of individual parameters or to develop confidence regions for two or more parameters, requires that the distribution of the estimated parameters is known or can be measured. Actually, the sampling distributions of parameters of biological importance are often unknown or difficult to be characterized. From what it has been described about the influences playing on endothelial function, it is easy to understand how it cannot exist a standard CFR value of reference common to all people, because simply varies rapidly from person to person and even in the same individual, depending on his state of psycho-social or physical stress, on his emotions, alimentation etc. From the network point of view, no biological parameter measured in clinical practice can be separated from the other. As an example, plasmatic cholesterol and troponin vary their own levels after a simple mental stress [43,330-333], or inflammation parameters and fibrinogen vary with emotions of happiness or sadness [334]. Given the individual variance, is very superficial perform clinical studies to measure risk thresholds (that will become clinical guidelines) [48] without taking into account the psychological characteristics of the population studied, assuming that these elements vary depending only with physical activity, alimentation and a set of gene activation that is fix and unchangeable. By the vision described up to here, it 's not strange to notice that those who want to assess hypothetical risk thresholds do not take into account these concepts and states, for example, not being able to explain the pathophysiological reasons for the release of low doses of troponin from some patients [335]. They simply ignore completely the perspective of the network, in favor of a simplistic, mechanistic and reductionist mentality, that simply not longer holds standing.

Actually, as has been clearly explained McCormack et al. [336], researchers can look at very similar data yet having completely different conclusions based purely on an over-reliance of statistical significance and an unclear understanding of confidence intervals. According to the authors, observations and results should speak for themselves, without the need for interpretations, and even if a threshold seems reasonable, it can never be used to make dichotomous conclusions. [336] Clinicians have not to use trials like drunks do with street lamps: not to light but to lean against, even if the author is a scientist of fame [337]. Moreover, Giannoni et al. demonstrated that in nature and in human beings there is no kind of threshold and well explained how common clinical research procedures routinely produce false thresholds [338].

These considerations will be fundamental in the study of the PNEIcellular-molecular network dynamics that affect endothelial function and its evaluation, for example, by CFR. Furthermore, from all these observations, remains crucial in an impressive and overbearing manner the way all of us look at the reality. With statistics, while remaining an important and fundamental analysis tool, everyone can deny the obvious depending on how the reality is observed (Figure 6). For example, we must always remember that we are exploring a reality 


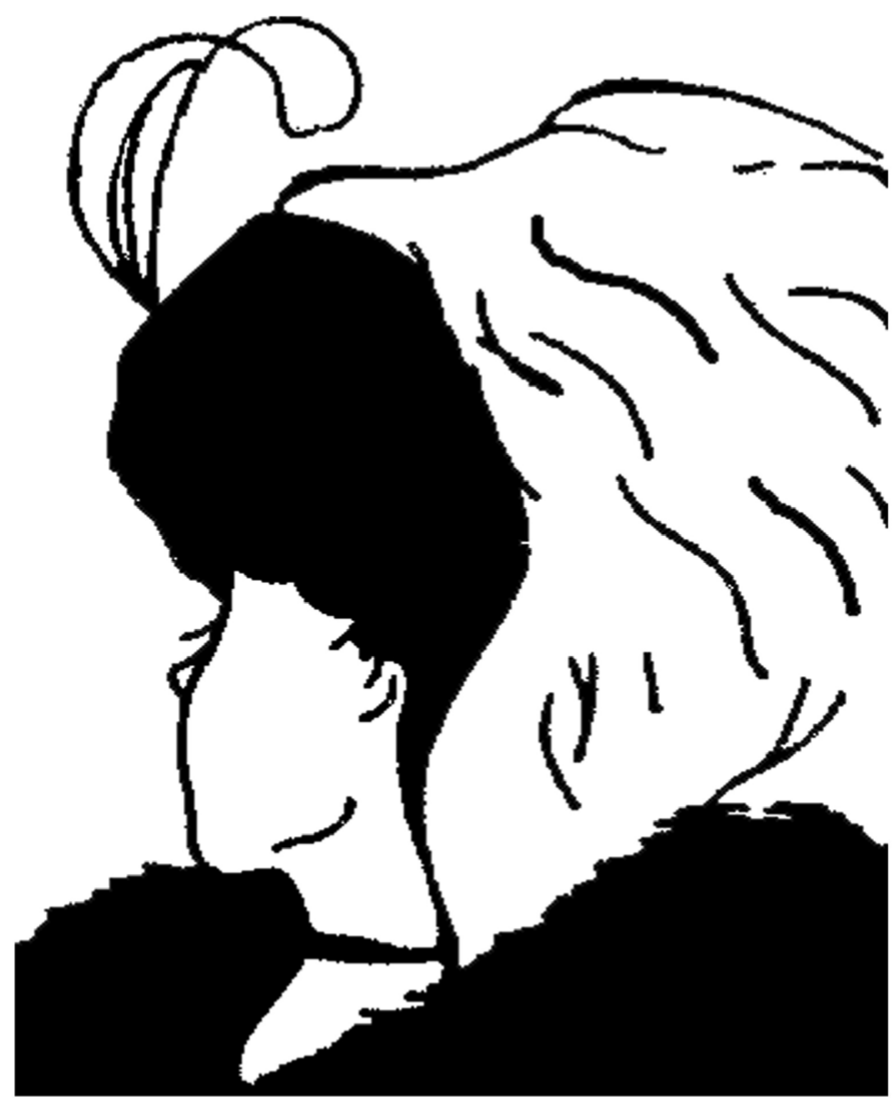

Figure 6. Gestaldt discipline tries to understand the laws by which we structure our perceptions. The perception of reality does not depend from the elements, but by the structuring of the elements. Thus, what we see is equivalent to how we see it and it is conditioned by past experiences. In this design, you recognize a young woman or an old lady? Then, depending on our point of view we use the statistics to describe the phenomenal associations observed. It must always be remembered, however, that showing associations between phenomena is not enough: it is essential to track a biological plausibility, a mechanism, in what is observed.

in which is already acting individual stress and that of generations before. What we consider "normal" might already be stressed out and so should not be taken as a reference point, a goal or as "objective".

\section{Considerations about the epigenetic regulation of the genome}

All cells in the body contain the same genome, but achieve their specific identity, through specific programs of gene expression. The way in which each cell type interprets genomic information is closely linked to the organization of DNA regulatory elements [339]. The Mendelian idea of the gene as a unit, the interpretation of genes as structural and/ or functional units in the genome is challenged by evidence showing the complexity and diversity of genomic organization [340,341].

Many disorders do not occur suddenly but are the result of a long process of adaptation involving psychological, nervous, endocrine and immune factors (as in case of endothelial function, atherosclerosis and myocardial infarction) [342-345]. Cytokines, hormones and neurotransmitters act every moment of our life regulating the expression of our genes and creating patterns of activation that can be transmitted to future generations [346] as a sort of "cellular memories", related to epigenetic signatures $[347,348]$.
Nowadays, geneticists say that some "classical genetic diseases or predisposition" can be connected to an alteration in the expression balance of genes [349,350], rather than the presence of a gene considered "sick", being the evidence that even many Mendelian diseases, cannot be explained by simple genotype-phenotype relationships [351,352].

In addition, also many cardiological pathologies are now related to an anomaly in the folding of proteins [353] at a post-transcriptional level in relation to the REDOX state of cardiac cells [354]. We have already seen how this state can be influenced by emotional distress.

Thus, from the point of view of epigenetic inheritance, many diseases could be interpreted as generational inheritance of adaptations to the environment and its various forms of stress.

Remaining in the perspective of the central dogma of DNA, who knows how many "genetic abnormalities" and "defective" proteins are present in people phenotypically normal and healthy; we do not know them because we do not see and study them, simply because those people have epigenetic balances that do not run into that state we call "disease".

Then, it makes sense to talk of "disharmony", of a "disease", nothing other than linking it to a specific external and internal environment (physical and psycho-social). The problem is not so much the presence of a single "sick" gene and its product, but its expression. It's obvious that, removing the gene from the DNA (Knock-out experiments), we won't look more a certain phenotype [355], but is not the only solution, and especially is not the way in which it seems to work the genome, which instead aims to regulate its expression in function of the environment. A gene can be silenced. The knock-out studies only show an association between the presence of a gene and its products and a pathology, but the setting of a precise genetic network is very wide, "often lie outside expected pathways" [341,356], and cannot be neglected.

In fact, as we will see, it is possible to change the cellular memories (related to our lives or transmitted by previous generations) acting on behaviors, nutrition and our emotions, taking advantage of the responses of the immune system [357].

Moreover, the single molecule of DNA responds to the environment: going down again in the molecular/atomic plane, our genes possess particular vibrational frequencies of resonance [358-361]. In particular, according to recent discoveries of molecular quantum physics, the DNA can be understood as the result of electromagnetic waves (in resonance with the cellular and macroscopic environment) that enable communication between cells $[362,363]$. Given the vibratory nature of DNA, researchers are studying the ways in which the genome is expressed, using special sounds [364-369].

In summary, a music consists of melody and harmony. By comparison with music: the genes are like the melody track; epigenetics is the harmony, the way of melody expression, that can "change music" even if the melody remains the same (please, to have an idea of this concept, listen to: 12 Variations on "Ah, vous tell-je, maman", KV265 (1778) WA Mozart (1756 - 1791), and watch: Nature video" Epigenome: The symphony in your cells", https://www.youtube.com/ watch? $\mathrm{v}=\mathrm{W} 3 \mathrm{Kg} 9 \mathrm{w}-\mathrm{srFk})$.

Thus, Epigenetics brought a big change of view in Biology and Medicine. In particular, it has been shown that some phenotypic changes, marked by methyl-signs on the genome, can be transmitted to the next generation [370]. Thanks to epigenetic evidences, has changed 
the scientific model applied in the field of classical genetics: may no longer exist the "gene-centrism" and so also the mechanistic and reductionist model of biology and medicine [371].

The genome is not a clear and distinct set of genes separate and unique that, changing randomly but surely, determines the unchangeable characteristics of an individual. Therefore, it is unthinkable to a genetic engineering in the narrow sense, namely the idea of addressing the health and disease as an engineer approaches any machine that knows the millimetric parts that compose it. Thinking of replacing a piece, a gene in the genetic network, implies to know exactly all the multiplicity of interactions that single gene sets with the rest of the network. Knowledge that no one has, and that is not expected we will have available in reasonable time, especially if much of the research is so determined to use the reductionist paradigm. This is not to say that classical genetic and genetic engineering are not the same useful and necessary. They are useful to increase the knowledge and the possibility of intervention, but without spreading the fable of treating diseases such as replacement of ill and failuring parts (genes) and without thinking of genes as a puppeteer, projects or simple vehicle of fix informations. Genes are active all the moments of our lives; they turn on and off each other and react to the environment. The molecular level demands a systemic approach. Looking back, we can say that thanks to the knowledge accumulated by the reductionist method, mechanistic and reductionist paradigm is entered in crisis. This is not a contradiction, is the reality that works dialectically.

\section{Epistemological effects of industry}

We are experiencing a very delicate and new situation in our story that had never made over the centuries: the decisive presence of the industry in the scientific field, and in medical science in particular. The huge influx of industry, that is the technique oriented by profit, is a destabilizing factor of the dominant medical model [98]. The profitoriented technical method, managed and replicated by major private systems, undermines the medical paradigm, not only because health has become a big business, and therefore a good that produces value for those who run it, but especially because it distorts the normal mechanisms of knowledge [372-376]. The mechanisms that scientists use to discover the "truth", which, in medicine, means adequate and plausible representation of pathophysiological processes, the genesis of diseases and their possible prevention and treatment. Today the industry is a powerful medical and philosophical school, which guides the ideals and scientific research, setting standards of testing, predetermining many answers.

It's the case even of the world of echocardiography that we use to asses endothelial function through CFR. We are witnessing a dramatic and expensive technological advancement, which aims to make perfectly measurable every aspect of cardiac function. This is obviously important, but in many cases it is not necessary in order to take clinical decisions. The resources may be optimized differently. In fact, the brain and medical knowledge are able to synthesize many more data of a machine, and to estimate with great accuracy using the simple "naked eye", much information, as shown by several studies about ejection fraction parameter [377-382].

While the world of Epigenetics and PNEI are changing radically the way of thinking about human life, on the other hand, the structure of medical knowledge, which determines the research, the health professions training and the medical structure, resists to change [383]. The effects are very painful and obvious, and recently have been summarized by Marvasati et al. [384]. Poor results, unsustainable costs, frequent medical errors, low satisfaction of patients and doctors and worsening inequalities in health. And again, the current medical model ignores the complex origin of diseases, medicalizes risk factors, makes "sick" asymptomatic persons, facilitating drugs treatments, decreeing the failure of prevention and, at the same time, the supremacy of patentable therapies that allow a profit. There is a tendency to a diagnostic inflation, leading to unjustified and inappropriate pharmacological treatments $[385,386]$. And this happens even in cardiology and oncology. For example, the American guidelines on the treatment of dyslipidemia lead to administer statins unnecessarily to one out of three adults [387-389], regardless of any study and any behavioral methodology relating to prevention of psychological stress that, as we have seen, increases the value of cholesterol. In the field of oncology is stated that many screening methods are able to identify "clinically insignificant tumors" with an increase of inappropriate treatments [390-392], the results of which are still scarce [393]. Research is providing more and more effective diagnostic tools. They are like increasingly powerful glasses - but needing glasses in the first place means not being able to see very well. The improvement of our investigative and diagnostic capability allows us to recognize early stage or mostly stable diseases in asymptomatic individuals. These patients are treated according to results from research conducted on more severe and acute conditions (overtreatment induced by over diagnosis). For example, the increased number of diagnoses of pulmonary embolism did not reduce the incidence of death, but increased the number of bleeding from subsequent anticoagulation therapy [394]. To avoid potential legal issues, we are doing more, with the risk of doing worse [394]. The model of medicine applied in acute situations does not match the needs of chronic diseases treatment. The striking example of this aspect comes from the lack of benefits of coronary revascularization compared to optimal medical therapy, in the case of stable coronary artery disease, although angiographically critical [395-398], or from the evidence that prolonged dual antiplatelet therapy following drug eluting stent increases major bleeding but is not associated with a decrease in composite rates of death or myocardial infarction $[399,400]$.

"You can make a lot of money, telling healthy people who are sick," said Moynihan, describing these phenomena [401,402]. The same mechanism has been well described by three distinguished doctors of international repute as Marcia Angell [403-405], Jerome Kassirer [406,407] and Richard Smith [408]. The most important thing of all processes described by these Authors, is that the industry is a conditioning factor of knowledge. It's clear that if the research world is in the hands of the industry, the epistemological field, namely the definition of the questions to meet by researchers and scientists, and also how they respond, it will be structured and shaped by the pharmaceutical market needs. This means that we can do without industry and drugs? Obviously not. According to the Authors mentioned above, we can imagine a simple public control of the companies, which produce no candy, but goods essential to health. In addition, there's the need to stop the pollution of scientific knowledge by industry to allow medical science to be free to move forward [409].

Ignoring the network perspective, continuing with a reductionist approach causes problems even in the world of medical emergency. The concrete example of the adrenergic receptors and inotropes

Inotropes have been fundamental to resuscitation of acute cardiogenic shock or for refractory heart failure treatment for decades 
[410,411]. While inotropes successfully increase cardiac output, their use is associated with an increased mortality [412], the risk of severe arrhythmias [413], increasing myocardial oxygen consumption [414] and possible myocardial ischemia [415,416]. Although different papers, based only on strictly hemodynamic pathophysiological assumptions, try to suggest the correct indication of use for each available inotropic drug, none of these considered the systemic effects of circulating catecholamines [417], how the adrenergic receptors are distributed in the heart [418-421] and in the PNEI network [422429], that their stimulation promote apoptosis and inflammation [430-435] or how they are up- or down-regulated [436] according to other drugs [437,438], neurohormonal influences [439-444] or in case of a disease state [445-449]. A same drug could produce, from this point of view, different and opposite effects according to adrenergic receptors distribution or expression [450]. There's also evidence that the epinephrine seems to cause more harm than good even in case of cardiac arrest [451,452]. Furthermore, a patient with an extensive acute myocardial infarction looses a part of his heart and the respective receptors, potentially making a drug less effective than another that would act in other vital areas [453]. Finally, the inotropic response to dobutamine may be reduced in patients previously treated with a beta-blocker. In a randomized, short-term study, pretreatment with carvedilol markedly reduced the inotropic response to dobutamine, whereas metoprolol had only a slight inhibitory effect. This difference may be due to the observation in experimental models that metoprolol, but not carvedilol, results in beta-1 receptor upregulation [454].

There's the pressing need for new inotropic agents that avoid some of the harmful effects of those actually available. New agents will be designed to improve systolic myocardial performance and we think that they will have to be projected and tested in models similar to the specific biological and clinical condition of their future use. This could be useful to optimize and amplify the new drugs effects, limiting their side effects, dosages and costs.

\section{The network perspective for future researches in heart transplantation. PNEI signals: a common soil for donor and recipient}

Rejection and coronary artery vasculopathy (CAV) is a complex disease with an unrevealed pathogenesis, that limits the long-term success of heart transplantation. As recently described by van de Hoogen et al. [455], rejection and CAV are not induced only by the donor or recipient but, nowadays, it is clear that there is some kind of synergic interaction between recipient and donor cells, which accelerates the pathogenesis of rejection or CAV [456-458].

To understand the details of this process, future research should consider a basic concept. The heart is inserted into the PNEI network and in it is inscribed the price of the accommodation to stress, the allostatic load, which is the wear and tear that results from chronic overactivity or underactivity of allostatic systems, during the individual life (extracellular matrix danger signals, cellular stress and PNEI system responses [459]). So we have to imagine that, at the time of the transplant, the recipient will have a particular psycho-neuro-endocrineimmune activation mode and functioning, which contributed to heart disease and led to heart failure. At the same time, in the heart of the donor, whithin cells and blood, are present PNEI molecules, circulating micro-RNAs and "allostatic signals": traces of how the physical and psychological stress (including death itself) have acted in the course of his life. These sensors and mediators will interact with the PNEI network of the recipient and will be received by the same, starting a new dialogue and establishing a new balance.

On this basis, it is scientifically possible to consider that a part of the rejection process and of the pathogenesis of CAV can be linked to a rejection of the receiver to memories or feelings of stress of the donor. And this could also enable future studies to clarify the molecular basis of the personality changes of heart transplant patients taking attitudes and memories of the donor, without ever being aware of his history or that they had no information about [460-462].

\section{References}

1. Tamayo T, Christian H, Rathmann W (2010) Impact of early psychosocial factors (childhood socioeconomic factors and adversities) on future risk of type 2 diabetes, metabolic disturbances and obesity: a systematic review. BMC Public Health 10: 525. [Crossref]

2. Zulman DM, Rosland AM, Choi H, Langa KM, Heisler M (2012) The influence of diabetes psychosocial attributes and self-management practices on change in diabetes status. Patient Educ Couns 87: 74-80. [Crossref]

3. De Kloet ER, Joëls M, Holsboer F (2005) Stress and the brain: from adaptation to disease. Nat Rev Neurosci 6: 463-75. [Crossref]

4. Klein JC, Crandall CG, Brothers RM, Carter JR (2010) Combined heat and mental stress alters neurovascular control in humans. J Appl Physiol 109: 1880-1886.

5. Hjortskov N, Rissén D, Blangsted AK, Fallentin N, Lundberg U, et al. (2004) The effect of mental stress on heart rate variability and blood pressure during computer work. Eur J ApplPhysiol 92: 84-9. [Crossref]

6. Garrett NA, Brasure M, Schmitz KH, Schultz MM, Huber MR (2004) Physical inactivity. Am J Prev Med 27: 304-309. [Crossref]

7. Kohl HW, Craig CL, Lambert EV, Inoue S, Alkandari JR, et al. (2012) The pandemic of physical inactivity: Global action for public health. Lancet 380: 294-305.

8. Gordon-Larsen P, McMurray RG, Popkin BM (2000) Determinants of adolescent physical activity and inactivity patterns. Pediatrics 105: E83. [Crossref]

9. Laufs U, Wassmann S, Czech T, Munzel T, Eisenhauer M, et al. (2005) Physical inactivity increases oxidative stress, endothelial dysfunction, and atherosclerosis. Arter Thromb Vasc Biol 25: 809-814. [Crossref]

10. Parrott AC (1999) Does cigarette smoking cause stress? Am Psychol 54: 817-820 [Crossref]

11. Cohen S, Kamarck T, Mermelstein R (1983) A global measure of perceived stress. $J$ Health Soc Behav24: 385-396[Crossref]

12. Finkelstein DM, Kubzansky LD, Goodman E (2006) Social Status, Stress, and Adolescent Smoking. J Adolesc Heal 39: 678-85. [Crossref]

13. Kassel JD, Stroud LR, Paronis CA (2003) Smoking, stress, and negative affect: correlation, causation, and context across stages of smoking. Psychol Bull 129: 270304. [Crossref]

14. VanItallie TB (2002) Stress: A risk factor for serious illness. Metabolism 51: 40-5. [Crossref]

15. Catalina-Romero C, Calvo E, Sánchez-Chaparro M a, Valdivielso P, et al. (2013). The relationship between job stress and dyslipidemia. Scand J Public Health 41: 142-149. [Crossref]

16. Van Reedt Dortland AKB, Vreeburg SA, Giltay EJ, Licht CMM, Vogelzangs N, et al. (2013) The impact of stress systems and lifestyle on dyslipidemia and obesity in anxiety and depression. Psychoneuroendocrinology 38: 209-18. [Crossref]

17. Marcondes FK, José V, Costa R, Sanches A, Cunha TS, et al. (2012) Dyslipidemia Induced by Stress. From Prev to Treat: 367-90.

18. Wadley AJ, Veldhuijzen van Zanten JJCS, Paine NJ, Drayson MT, et al. ( 2014) Underlying inflammation has no impact on the oxidative stress response to acute mental stress. Brain Behav Immun 2014;40: 182-190. [Crossref]

19. Sanchez-Gonzalez MA, Guzik P, May RW, Koutnik AP, Hughes R (2002) Trait anxiety mimics age-related cardiovascular autonomic modulation in young adults. $J$ Hum Hypertens 29: 274-280. [Crossref]

20. Kershaw KN, Diez Roux A V, Bertoni A, Carnethon MR, et al. (2015) Associations of chronic individual-level and neighbourhood-level stressors with incident coronary 
heart disease: the Multi-Ethnic Study of Atherosclerosis. J Epidemiol Community Health 69: 136-141. [Crossref]

21. Peters MN, Moscona JC, Katz MJ, Deandrade KB, Quevedo HC, et al. (2014) Natural disasters and myocardial infarction: the six years after Hurricane Katrina. Mayo Clin Proc 89: 472-477. [Crossref]

22. Vaccarino V, Shah AJ, Rooks C, Ibeanu I, Nye JA, et al. (2014) Pimple P, Salerno A, D’Marco L, Karohl C, Bremner JD, Raggi P. Sex differences in mental stress-induced myocardial ischemia in young survivors of an acute myocardial infarction. Psychosom Med 76: 171-180.

23. Mostofsky E, Penner EA, Mittleman MA (2014) Outbursts of anger as a trigger of acute cardiovascular events: a systematic review and meta-analysis. Eur Heart $J$ 35: 1404-1410. [Crossref]

24. Hendrickson CM, Neylan TC, Na B, Regan M, Zhang Q, et al. (2013) Cohen BE. Lifetime trauma exposure and prospective cardiovascular events and all-cause mortality: Findings from the Heart and Soul Study. Psychosom Med 75: 849-55. [Crossref]

25. Vaccarino V, Goldberg J, Rooks C, Shah AJ, Veledar E, et al. (2013) Faber TL, Votaw JR, Forsberg CW, Bremner JD. Post-traumatic stress disorder and incidence of coronary heart disease: a twin study. J Am Coll Cardiol 62: 970-978[Crossref]

26. Nemeroff $\mathrm{CB}$, Goldschmidt-Clermont PJ. Heartache and heartbreak--the link between depression and cardiovascular disease. Nat Rev Cardiol 9: 526-539.

27. Dantzer R, O'Connor JC, Freund GG, Johnson RW, Kelley KW (2008) From inflammation to sickness and depression: when the immune system subjugates the brain. Nat Rev Neurosci 9: 46-56.[Crossref]

28. Maes M (2011) Depression is an inflammatory disease, but cell-mediated immune activation is the key component of depression. Prog Neuropsychopharmacol Biol Psychiatry 35: 664-675. [Crossref]

29. Schiepers OJG, Wichers MC, Maes M (2005) Cytokines and major depression. Prog Neuro-Psychopharmacology Biol Psychiatry 29: 201-217. [Crossref]

30. Ormonde do Carmo MBO, Mendes-Ribeiro AC, Matsuura C, Pinto VL, et al. (2015) Major depression induces oxidative stress and platelet hyperaggregability. $J$ Psychiatr Res 61: 19-24 [Crossref]

31. Vidović A, Grubišić-Ilić M, Kozarić-Kovačić D, Gotovac K, Rakoš I, et al. (2011) Exaggerated platelet reactivity to physiological agonists in war veterans with posttraumatic stress disorder. Psychoneuroendocrinology 36: 161-172. [Crossref]

32. Samad Z, Boyle S, Ersboll M, Vora AN, Zhang Y, et al. (2014) Sex differences in platelet reactivity and cardiovascular and psychological response to mental stress in patients with stable ischemic heart disease: insights from the REMIT study. $J$ Am Coll Cardiol 64: 1669-1678. [Crossref]

33. Cho KI, Shim W-J, Park S-M, Kim M-A, Kim H-L, et al. (2015) Association of depression with coronary artery disease and QTc interval prolongation in women with chest pain: Data from the KoRean wOmen'S chest pain rEgistry (KoROSE) study. Physiol Behav 143: 45-50. [Crossref]

34. Jackson AR, Nagarkatti P, Nagarkatti M (2014) Anandamide attenuates Th-17 cellmediated delayed-type hypersensitivity response by triggering IL-10 production and consequent microRNA induction. PLoS One 9: e93954. [Crossref]

35. Dlugos A, Childs E, Stuhr KL, Hillard CJ, de Wit H (2012) Acute Stress Increases Circulating Anandamide and Other N-Acylethanolamines in Healthy Humans. Neuropsychopharmacology 37: 2416-2427. [Crossref]

36. Gray JM, Vecchiarelli HA, Morena M, Lee TTY, Hermanson DJ, et al. (2015) Corticotropin-releasing hormone drives anandamide hydrolysis in the amygdala to promote anxiety. J Neurosci 35: 3879-3892. [Crossref]

37. Hill MN, Miller GE, Carrier EJ, Gorzalka BB, Hillard CJ (2009) Circulating endocannabinoids and $\mathrm{N}$-acyl ethanolamines are differentially regulated in major depression and following exposure to social stress. Psychoneuroendocrinology 34: 1257-1262. [Crossref]

38. Heyman E, Gamelin FX, Goekint M, Piscitelli F, Roelands B, et al. (2012) Intense exercise increases circulating endocannabinoid and BDNF levels in humans-Possible implications for reward and depression. Psychoneuroendocrinology 37: 844-851. [Crossref]

39. Holman EA, Guijarro A, Lim J, Piomelli D (2014) Effects of acute stress on cardiac endocannabinoids, lipogenesis, and inflammation in rats. Pychosom Med 76: 20-28. [Crossref]

40. Bossong MG, van Hell HH, Jager G, Kahn RS, Ramsey NF, et al. (2013) The endocannabinoid system and emotional processing: A pharmacological fMRI study with \{increment\}9-tetrahydrocannabinol. Eur Neuropsychopharmacol 23: 1687-1697. [Crossref]

41. Grissom GR, Phillips RA (2005) Screening for depression: this is the heart of the matter. Arch Intern Med 165: 1214-1216.[Crossref]

42. Redmond N, Richman J, Gamboa CM, Albert MA, Sims M, et al. (2013) Perceived stress is associated with incident coronary heart disease and all-cause mortality in lowbut not high-income participants in the Reasons for Geographic And Racial Differences in Stroke study. J Am Heart Assoc 2: e000447. [Crossref]

43. Lazzarino AI, Hamer M, Gaze D, Collinson P, Steptoe A (2013) The association between cortisol response to mental stress and high-sensitivity cardiac troponin $\mathrm{T}$ plasma concentration in healthy adults. J Am Coll Cardiol 62: 1694-701. [Crossref]

44. Stetkiewicz-Lewandowicz A, Borkowska A, Sobów T (2014) Temperament and character traits measured by temperament and character inventory (TCI) by Cloninger in patients with ischemic heart disease. Pol Merkur Lekarski 37: 159-162. [Crossref]

45. Lee HB, Bienvenu OJ, Cho S-J, Ramsey CM, Bandeen-Roche K, et al. (2010) Personality disorders and traits as predictors of incident cardiovascular disease: findings from the 23-year follow-up of the Baltimore ECA study. Psychosomatics 51 289-296. [Crossref]

46. Löckenhoff CE, Terracciano A, Patriciu NS, Eaton WW, Costa PT Jr (2009) Selfreported extremely adverse life events and longitudinal changes in five-factor model personality traits in an urban sample. J Trauma Stress 22: 53-59. [Crossref].

47. Lee HB, Offidani E, Ziegelstein RC, Bienvenu OJ, Samuels J, et al. (2014) FiveFactor Model Personality Traits as Predictors of Incident Coronary Heart Disease in the Community: A 10.5-Year Cohort Study Based on the Baltimore Epidemiologic Catchment Area Follow-Up Study. Psychosomatics 55: 352-361. [Crossref]

48. Camm AJ, Luscher TF, Serruys PW (2009) ESC Textbook of Cardiovascular Medicine Second Edition. Oxford Med 1-1398.

49. Rozanski A, Blumenthal JA, Kaplan J (1999) Impact of psychological factors on the pathogenesis of cardiovascular disease and implications for therapy. Circulation 99: 2192-2217. [Crossref]

50. Matsunaga M, Sato S, Isowa T, Tsuboi H, Konagaya T, et al. (2009) Profiling of serum proteins influenced by warm partner contact in healthy couples. Neuroendocrinol Lett 30: 227-236. [Crossref]

51. Steptoe A, Wardle J, Marmot M (2005) Positive affect and health-related neuroendocrine, cardiovascular, and inflammatory processes. Proc Natl Acad Sci U S A 102: 6508-6512. [Crossref]

52. Steptoe A, Gibson EL, Hamer M, Wardle J (2007) Neuroendocrine and cardiovascular correlates of positive affect measured by ecological momentary assessment and by questionnaire. Psychoneuroendocrinology 32: 56-64. [Crossref]

53. Steptoe A, O'Donnell K, Badrick E, Kumari M, Marmot M (2008) Neuroendocrine and inflammatory factors associated with positive affect in healthy men and women: the Whitehall II study. Am J Epidemiol 167: 96-102. [Crossref]

54. Bostock S, Hamer M, Wawrzyniak AJ, Mitchell ES, Steptoe A (2011) Positive emotional style and subjective, cardiovascular and cortisol responses to acute laboratory stress. Psychoneuroendocrinology 36: 1175-1183. [Crossref]

55. Uzarski JS, Scott EW, McFetridge PS (2013) Adaptation of endothelial cells to physiologically-modeled, variable shear stress. PLoS One 8: e57004. [Crossref]

56. Li Y, Zheng J, Bird IM, Magness RR (2005) Effects of pulsatile shear stress on signaling mechanisms controlling nitric oxide production, endothelial nitric oxide synthase phosphorylation, and expression in ovine fetoplacental artery endothelial cells. Endothelium 12: 21-39.

57. Gafarov VV, Panov DO, Gromova EA, Gagulin IV, Gafarova AV (2013) The influence of social support on risk of acute cardiovascular diseases in female population aged 25 64 in Russia. Int J Circumpolar Health 72. [Crossref]

58. Hughes A, McMunn A, Bartley M, Kumari M (2015) Elevated inflammatory biomarkers during unemployment: modification by age and country in the UK. $J$ Epidemiol Community Health 69: 673-679. [Crossref]

59. Dogdu O, Yarlioglues M, Kaya MG, Ardic I, Akpek M, et al. (2012) Relationship between psychosocial status, diabetes mellitus, and left ventricular systolic function in patients with stable multivessel coronary artery disease. Cardiol J 19: 249-255. [Crossref]

60. Inoue N (2014) Stress and atherosclerotic cardiovascular disease. J Atheroscler Thromb 21: 391-401. [Crossref] 
61. Cho J-H, Lee I, Hammamieh R, Wang K, Baxter D, et al. (2014) Molecular evidence of stress-induced acute heart injury in a mouse model simulating posttraumatic stress disorder. Proc Natl Acad Sci US A 111: 3188-3193. [Crossref]

62. Meloni M. (2014) The social brain meets the reactive genome: neuroscience, epigenetics and the new social biology. Front Hum Neurosci 8: 309

63. Demertzi A, Liew C, Ledoux D, Bruno MA, Sharpe M, et al. (2009) Dualism persists in the science of mind. Ann N Y Acad Sci 1157: 1-9. [Crossref]

64. McEwen BS, Morrison JH (2013) The brain on stress: vulnerability and plasticity of the prefrontal cortex over the life course. Neuron 79: 16-29. [Crossref]

65. Dhabhar FS, McEwen BS (1997) Acute stress enhances while chronic stress suppresses cell-mediated immunity in vivo: a potential role for leukocyte trafficking. Brain Behav Immun 11: 286-306. [Crossref]

66. Charmandari E, Tsigos C, Chrousos G(2005) Endocrinology of the stress response. Annu Rev Physiol 67: 259-84. [Crossref]

67. Chrousos G, Gold P (1992) The Concepts of Stress and Stress System Disorders Overview of. JAMA: 267: 1244-52

68. Dantzer R, Kelley KW (2007) Twenty years of research on cytokine-induced sickness behavior. Brain Behav Immun 21: 153-160. [Crossref]

69. Anticevic A, Cole MW, Murray JD, Corlett PR, Wang XJ, et al. (2012) The role of default network deactivation in cognition and disease. Trends Cogn Sci 16: 584-592. [Crossref]

70. Buckner RL, Andrews-Hanna JR, Schacter DL (2008) The brain's default network: anatomy, function, and relevance to disease. Ann N Y Acad Sci 1124: 1-38. [Crossref]

71. Otti A, Gündel H, Wohlschläger A, Zimmer C, Sorg C, et al. (2012) Default mode network of the brain. Neurobiology and clinical significance. Nervenarzt 83: 16, 18-24. [Crossref]

72. Ader R. Psychoneuroimmunology, Two-Volume Set. Elsevier; 2011: 1-1269

73. Thayer JF, Lane RD (2009) Claude Bernard and the heart-brain connection: further elaboration of a model of neurovisceral integration. Neurosci Biobehav Rev 33: 81-88. [Crossref]

74. Shaffer F, McCraty R2, Zerr CL1 (2014) A healthy heart is not a metronome: an integrative review of the heart's anatomy and heart rate variability. Front Psychol 5: 1040. [Crossref]

75. Hagemann D, Waldstein SR, Thayer JF (2003) Central and autonomic nervous system integration in emotion. Brain Cogn 52: 79-87. [Crossref]

76. Thayer JF, Brosschot JF (2005) Psychosomatics and psychopathology: looking up and down from the brain. Psychoneuroendocrinology 30: 1050-1058. [Crossref]

77. Thayer JF, Lane RD (2009) Claude Bernard and the heart-brain connection: further elaboration of a model of neurovisceral integration. Neurosci Biobehav Rev 33: 81-88. [Crossref]

78. Thayer JF, Hansen AL, Saus-Rose E, Johnsen BH (2009) Heart rate variability, prefrontal neural function, and cognitive performance: the neurovisceral integration perspective on self-regulation, adaptation, and health. Ann Behav Med 37: 141-153. [Crossref]

79. Richard Jennings J, Allen B, Gianaros PJ, Thayer JF, Manuck SB (2015) Focusing neurovisceral integration: cognition, heart rate variability, and cerebral blood flow. Psychophysiology 52: 214-224. [Crossref]

80. Thayer JF, Lane RD (2000) A model of neurovisceral integration in emotion regulation and dysregulation. J Affect Disord 61: 201-216. [Crossref]

81. Hansen AL, Johnsen BH, Sollers JJ, Stenvik K, Thayer JF (2004) Heart rate variability and its relation to prefrontal cognitive function: the effects of training and detraining. Eur J Appl Physiol 93: 263-272. [Crossref]

82. Park G, Van Bavel JJ, Vasey MW, Egan EJL, Thayer JF (2012) From the heart to the mind's eye: cardiac vagal tone is related to visual perception of fearful faces at high spatial frequency. Biol Psychol 90: 171-178. [Crossref]

83. Park G, Van Bavel JJ, Vasey MW, Thayer JF (2012) Cardiac vagal tone predicts inhibited attention to fearful faces. Emotion 12: 1292-1302. [Crossref]

84. Williams DP, Cash C, Rankin C, Bernardi A, Koenig J, et al. (2015) Resting heart rate variability predicts self-reported difficulties in emotion regulation: a focus on different facets of emotion regulation. Front Psychol 6: 261. [Crossref]

85. Weber CS, Thayer JF, Rudat M, Wirtz PH, Zimmermann-Viehoff F, et al. (2010)
Low vagal tone is associated with impaired post stress recovery of cardiovascular, endocrine, and immune markers. Eur J Appl Physiol 109: 201-211. [Crossref]

86. Luciano S. Psicofisiologia (2009) Dalla genetica comportamentale alle attività cognitive. Zanichelli 2009: 1-224.

87. Brewer JA, Worhunsky PD, Gray JR, Tang YY, Weber J, et al. (2011) Meditation experience is associated with differences in default mode network activity and connectivity. Proc Natl Acad Sci U S A 108: 20254-20259. [Crossref]

88. Fox M, et al. (2005) The human brain is intrinsically organized into dynamic, anticorrelated functional networks. Proceedings of the National Academy of Sciences of the United States of America 102: 9673-9678. [Crossref]

89. Fransson P (2005) Spontaneous low-frequency BOLD signal fluctuations: an fMR investigation of the resting-state default mode of brain function hypothesis. Hum Brain Mapp 26: 15-29. [Crossref]

90. Seeley WW, Menon V, Schatzberg AF, Keller J, Glover GH, et al. (2007) Dissociable intrinsic connectivity networks for salience processing and executive control. $J$ Neurosci 27: 2349-2356. [Crossref]

91. Schmidt S., Meditation - Neuroscientific Approaches and Philosophical Implications. Ed. Spinger, 2014.

92. Barnes VA, Orme-Johnson DW (2012) Prevention and Treatment of Cardiovascular Disease in Adolescents and Adults through the Transcendental Meditation( $\left({ }^{\circledR}\right)$ Program: A Research Review Update. Curr Hypertens Rev 8: 227-242. [Crossref]

93. Kay BP, Meng X, Difrancesco MW, Holland SK, Szaflarski JP (2012) Moderating effects of music on resting state networks. Brain Res 1447: 53-64. [Crossref]

94. Lin LC, Chiang CT, Lee MW, Mok HK, Yang YH, et al. (2013) Parasympathetic activation is involved in reducing epileptiform discharges when listening to Mozart music. Clin Neurophysiol 124: 1528-1535. [Crossref]

95. Lin LC, Lee W Te, Wu HC, Tsai CL, Wei RC, et al. (2010) Mozart K.448 and epileptiform discharges: Effect of ratio of lower to higher harmonics. Epilepsy Res 89: 238-245. [Crossref]

96. Dinan TG, Cryan JF (2012) Regulation of the stress response by the gut microbiota implications for psychoneuroendocrinology. Psychoneuroendocrinology 37: 13691378. [Crossref]

97. Zimmer J, Lange B, Frick J-S, Sauer H, Zimmermann K, et al. (2012) A vegan or vegetarian diet substantially alters the human colonic faecal microbiota. Eur J Clin Nutr 66: 53-60. [Crossref]

98. Bottaccioli F (2005) Psiconeuroendocrinoimmunologia. I fondamenti scientifici delle relazioni mente-corpo. Le basi razionali della medicina integrata Red! Il Castello Group 1-507.

99. Quyyumi AA (1998) Endothelial function in health and disease: new insights into the genesis of cardiovascular disease. Am J Med 105: 32S - 39S. [Crossref]

100. Bischoff J, Aikawa E (2011) Progenitor cells confer plasticity to cardiac valve endothelium. J Cardiovasc Transl Res 4: 710-719. [Crossref]

101. Ali OA, Chapman M, Nguyen TH, Chirkov YY, Heresztyn T, et al. (2014) Interactions between inflammatory activation and endothelial dysfunction selectively modulate valve disease progression in patients with bicuspid aortic valve. Heart 100: 800-805. [Crossref]

102. Vaturi M, Perl L, Leshem-Lev D, Dadush O, Bental T, et al. (2011) Circulating endothelial progenitor cells in patients with dysfunctional versus normally functioning congenitally bicuspid aortic valves. Am J Cardiol 108: 272-276. [Crossref]

103. Sun L, Rajamannan NM, Sucosky P (2013) Defining the role of fluid shear stress in the expression of early signaling markers for calcific aortic valve disease. PLoS One 8: e84433. [Crossref]

104. Towler DA (2013) Molecular and cellular aspects of calcific aortic valve disease. Circ Res 113: 198-208. [Crossref]

105. Bosse K, Hans CP, Zhao N, Koenig SN, Huang N, et al. (2013) Endothelial nitric oxide signaling regulates Notch1 in aortic valve disease. J Mol Cell Cardiol 60: 27 35. [Crossref]

106. Bozbas H, Pirat B, Yildirir A, SimÅŸek V, Sade E, et al. (2008) Coronary flow reserve is impaired in patients with aortic valve calcification. Atherosclerosis 197: 846-852. [Crossref]

107. Wang H, Leinwand LA, Anseth KS (2014) Cardiac valve cells and their microenvironment--insights from in vitro studies. Nat Rev Cardiol 11: 715-727. [Crossref] 
108. Salhiyyah K, Yacoub MH, Chester AH (2011) Cellular mechanisms in mitral valve disease. J Cardiovasc Transl Res 4: 702-709.[Crossref]

109. Idriss NK, Blann AD, Sayed DM, Gaber MA, Hassen HA, et al. (2014) Circulating endothelial cells and platelet microparticles in mitral valve disease with and without atrial fibrillation. Angiology 66: 631-637. [Crossref]

110. Bozbas H, Pirat B, Yildirir A, Simsek V, Sade E, et al. (2008) Mitral annular calcification associated with impaired coronary microvascular function. Atherosclerosis 198: 11521. [Crossref]

111. Moesgaard SG, Klostergaard C, Zois NE, Teerlink T, Molin M, et al. (2012) Flow-mediated vasodilation measurements in Cavalier King Charles Spaniels with increasing severity of myxomatous mitral valve disease. $J$ Vet Intern Med 26: 61-68. [Crossref]

112. Katoh S, Honda S, Watanabe T, Suzuki S, Ishino M, et al. (2014) Atrial endothelial impairment through Toll-like receptor 4 signaling causes atrial thrombogenesis. Heart Vessels 29: 263-272. [Crossref]

113. Škerk V, Markotić A, Delić Brkljačić D, Manola S, Krčmar T,et al. (2013) The association of ventricular tachycardia and endothelial dysfunction in the setting of acute myocardial infarction with ST elevation. Med Sci Monit 19: 1027-1036. [Crossref]

114. Harada K, Aoki M, Toyono M, Tamura M (2004) Coronary flow velocity and coronary flow velocity reserve in children with ventricular septal defect. Tohoku J Exp Med 202: 77-85. [Crossref]

115. Dedkov EI, Perloff JK, Tomanek RJ, Fishbein MC, Gutterman DD (2006) The coronary microcirculation in cyanotic congenital heart disease. Circulation 114: 196200. [Crossref]

116. Tona F, Caforio ALP, Iliceto S (2007) Microvascular dysfunction in left apical ballooning syndrome: Primary cause or secondary phenomenon? Eur J Echocardiogr. [Crossref]

117. Tona F (1884) Dilated cardiomyopathy and coronary flow reserve. Eur Heart $J$ 27: author reply 1884-5. [Crossref]

118. Vecchiati A, Tellatin S, Angelini A, Iliceto S, Tona F (2014) Coronary microvasculopathy in heart transplantation: Consequences and therapeutic implications. World J Transplant 4: 93-101 [Crossref]

119. Tona F, Osto E, Tarantini G, Gambino A, Cavallin F, et al. (2010) Coronary flow reserve by transthoracic echocardiography predicts epicardial intimal thickening in cardiac allograft vasculopathy. Am J Transplant 10: 1668-1676. [Crossref]

120. Roura S, Bayes-Genis A (2009) Vascular dysfunction in idiopathic dilated cardiomyopathy. Nat Rev Cardiol 6: 590-598. [Crossref]

121. Osto E, Tona F, De Bon E, Iliceto S, Cella G (2010) Endothelial dysfunction in cardiac allograft vasculopathy: potential pharmacological interventions. Curr Vasc Pharmacol 8: 169-88 [Crossref]

122. Osto E, Castellani C, Fadini GP, Baesso I, Gambino A, et al. (2011) Impaired endothelial progenitor cell recruitment may contribute to heart transplant microvasculopathy. $J$ Heart Lung Transplant 30: 70-76. [Crossref]

123. Halcox JP, Schenke WH, Zalos G, Mincemoyer R, Prasad A, et al. (2002) Prognostic value of coronary vascular endothelial dysfunction. Circulation 106: 653-658. [Crossref]

124. Dal Lin C, Tona F, Osto E (2015) Coronary Microvascular Function and Beyond: The Crosstalk between Hormones, Cytokines, and Neurotransmitters. Int J Endocrinol 2015 .

125. Li L, Jia Z, Xu L, Wu Y, Zheng Q (2014) Expression profile of neuro-endocrineimmune network in rats with vascular endothelial dysfunction. Korean $J$ Physiol Pharmacol 18: 177-182. [Crossref]

126. Davel AP, Wenceslau CF, Akamine EH, Xavier FE, Couto GK, et al. (2011) Endothelial dysfunction in cardiovascular and endocrine-metabolic diseases: an update. Braz J Med Biol Res 44: 920-932. [Crossref]

127. Seddon MD, Chowienczyk PJ, Brett SE, Casadei B, Shah AM (2008) Neuronal nitric oxide synthase regulates basal microvascular tone in humans in vivo. Circulation 117 : 1991-1996. [Crossref]

128. Naqvi TZ, Hyuhn HK (2009) Cerebrovascular mental stress reactivity is impaired in hypertension. Cardiovasc Ultrasound 7: 32. [Crossref]

129. Gottdiener JS, Kop WJ, Hausner E, McCeney MK, Herrington D, Krantz DS (2003)
Effects of mental stress on flow-mediated brachial arterial dilation and influence of behavioral factors and hypercholesterolemia in subjects without cardiovascular disease. Am J Cardiol 92: 687-691. [Crossref]

130. Xue YT, Tan QW, Li P, Mou SF, Liu SJ, et al. (2015) Investigating the role of acute mental stress on endothelial dysfunction: a systematic review and meta-analysis. Clin Res Cardiol 104: 310-319. [Crossref]

131. Schwartz BG, French WJ, Mayeda GS, Burstein S, Economides C, et al. (2012) Emotional stressors trigger cardiovascular events. Int $J$ Clin Pract 66: 631-639. [Crossref]

132. Lund-Johansen P (1994) Newer thinking on the hemodynamics of hypertension. Cur Opin Cardiol 9: 505-511. [Crossref]

133. Erickson MA, Dohi K, Banks WA (2012) Neuroinflammation: a common pathway in CNS diseases as mediated at the blood-brain barrier. Neuroimmunomodulation 19 : 121-130. [Crossref]

134. Ghiadoni L, Donald AE, Cropley M, Mullen MJ, Oakley G, et al. (2000) Mental stress induces transient endothelial dysfunction in humans. Circulation 102: 2473-2478. [Crossref]

135. Spieker LE, Hürlimann D, Ruschitzka F, Corti R, Enseleit F, et al. (2002) Mental stress induces prolonged endothelial dysfunction via endothelin-A receptors. Circulation 105: 2817-2820. [Crossref]

136. Vaccarino V, Votaw J, Faber T, Veledar E, Murrah NV, et al. (2009) Major depression and coronary flow reserve detected by positron emission tomography. Arch Intern Med 169: 1668-1676. [Crossref]

137. Wei J, Pimple P, Shah AJ, Rooks C, Bremner JD, et al. (2014) Depressive symptom are associated with mental stress-induced myocardial ischemia after acute myocardial infarction. PLoS One9: e102986.[Crossref]

138. Rodgers AB, Morgan CP, Bronson SL, Revello S, Bale TL (2013) Paternal stress exposure alters sperm microRNA content and reprograms offspring HPA stress axis regulation. J Neurosci 33: 9003-12. [Crossref]

139. Seckl JR, Holmes MC (2007) Mechanisms of disease: glucocorticoids, their placental metabolism and fetal 'programming' of adult pathophysiology. Nat Clin Pract Endocrinol Metab 3: 479-488. [Crossref]

140. Reynolds RM (2013) Glucocorticoid excess and the developmental origins of disease: two decades of testing the hypothesis--2012 Curt Richter Award Winner. Psychoneuroendocrinology 38: 1-11. [Crossref]

141. Harris A, Seckl J (2011) Glucocorticoids, prenatal stress and the programming of disease. Horm Behav 59: 279-289. [Crossref]

142. Zucchi FC, Yao Y, Ward ID, Ilnytskyy Y, Olson DM, et al. (2013) Maternal stress induces epigenetic signatures of psychiatric and neurological diseases in the offspring. PLoS One 8: e56967. [Crossref]

143. Babenko O, Kovalchuk I, Metz GA (2015) Stress-induced perinatal and transgenerational epigenetic programming of brain development and mental health Neurosci Biobehav Rev 48: 70-91. [Crossref]

144. McEwen BS (2002) Protective and damaging effects of stress mediators: the good and bad sides of the response to stress. Metabolism 51: 2-4. [Crossref]

145. McEwen BS (2006) Protective and damaging effects of stress mediators: central role of the brain. Dialogues Clin Neurosci 8: 367-381. [Crossref]

146. McEwen BS, Eiland L, Hunter RG, Miller MM (2012) Stress and anxiety: structural plasticity and epigenetic regulation as a consequence of stress. Neuropharmacology 62: 3-12. [Crossref]

147. Kember G, Armour JA, Zamir M (2013) Dynamic neural networking as a basis for plasticity in the control of heart rate. J Theor Biol 317: 39-46. [Crossref]

148. Yirmiya R, Goshen I (2011) Immune modulation of learning, memory, neural plasticity and neurogenesis. Brain Behav Immun 25: 181-213. [Crossref]

149. Sng J, Meaney MJ (2009) Environmental regulation of the neural epigenome Epigenomics 1: 131-151. [Crossref]

150. Fragala MS, Kraemer WJ, Denegar CR, Maresh CM, Mastro AM, et al. (2011) Neuroendocrine-immune interactions and responses to exercise. Sports Med 41: 621639. [Crossref]

151. Monticelli S, Natoli G (2013) Short-term memory of danger signals and environmental stimuli in immune cells. Nat Immunol 14: 777-784. [Crossref] 
152. Harbuz M (2003) Neuroendocrine-immune interactions. Trends Endocrinol Metab 14: 51-52. [Crossref]

153. Starcke K, Brand M (2012) Decision making under stress: a selective review. Neurosci Biobehav Rev 36: 1228-1248. [Crossref]

154. Thayer JF, Sternberg E (2006) Beyond heart rate variability: vagal regulation of allostatic systems. Ann N Y Acad Sci 1088: 361-372. [Crossref]

155. Yusuf S, Reddy S, Ounpuu S, Anand S (2001) Global burden of cardiovascular diseases: part I: general considerations, the epidemiologic transition, risk factors, and impact of urbanization. Circulation 104: 2746-2753.[Crossref]

156. Yusuf S, Reddy S, Ounpuu S, Anand S (2004) Global burden of cardiovascular diseases: Part II: variations in cardiovascular disease by specific ethnic groups and geographic regions and prevention strategies. Circulation 104: 2855-2864. [Crossref]

157. Weinstein MC, Coxson PG, Williams LW, Pass TM, Stason WB, et al. (1987) Forecasting coronary heart disease incidence, mortality, and cost: the Coronary Heart Disease Policy Model. Am J Public Health 77: 1417-1426. [Crossref]

158. Dotevall A, Rosengren A, Lappas G, Wilhelmsen L (2000) Does immigration contribute to decreasing CHD incidence? Coronary risk factors among immigrants in Göteborg, Sweden. J Intern Med 247: 331-339. [Crossref]

159. Selye H (1998) A syndrome produced by diverse nocuous agents. 1936. J Neuropsychiatry Clin Neurosci 10: 230-231. [Crossref]

160. Wang RP, Yao Q, Xiao YB, Zhu SB, Yang L, et al. (2011) Toll-like receptor 4/nuclear factor-kappa $\mathrm{B}$ pathway is involved in myocardial injury in a rat chronic stress model. Stress 14: 567-575. [Crossref]

161. Gordan R, Gwathmey JK, Xie LH (2015) Autonomic and endocrine control of cardiovascular function. World J Cardiol 7: 204-214. [Crossref]

162. Agutter PS (2007) Cell mechanics and stress: from molecular details to the 'universal cell reaction' and hormesis. Bioessays 29: 324-333. [Crossref]

163. Boulon S, Westman BJ, Hutten S, Boisvert FM, Lamond AI (2010) The nucleolus under stress. Mol Cell 40: 216-227. [Crossref]

164. Wills MK, Jones N (2012) Teaching an old dogma new tricks: twenty years of Shc adaptor signalling. Biochem J 447: 1-16. [Crossref]

165. Barbour JA, Turner N (2014) Mitochondrial stress signaling promotes cellular adaptations. Int J Cell Biol 2014: 156020. [Crossref]

166. Luo J, Nikolaev AY, Imai S, Chen D, Su F, et al. (2001) Negative control of p53 by Sir2alpha promotes cell survival under stress. Cell 107: 137-148. [Crossref]

167. Cook B, Hardy RW, McConnaughey WB, Zuker CS (2008) Preserving cell shape under environmental stress. Nature 452: 361-364. [Crossref]

168. Kiehl TR, Shen D, Khattak SF, Jian Li Z, Sharfstein ST (2011) Observations of cell size dynamics under osmotic stress. Cytometry A 79: 560-569. [Crossref]

169. Mirouse V, Swick LL, Kazgan N, St Johnston D, Brenman JE (2007) LKB1 and AMPK maintain epithelial cell polarity under energetic stress. J Cell Biol 177: 387 392. [Crossref]

170. Hetz C (2012) The unfolded protein response: controlling cell fate decisions under ER stress and beyond. Nat Rev Mol Cell Biol 13: 89-102. [Crossref]

171. Li B, Yi P, Zhang B, Xu C, Liu Q, et al. (2011) Differences in endoplasmic reticulum stress signalling kinetics determine cell survival outcome through activation of MKP1. Cell Signal 23: 35-45. [Crossref]

172. Logue SE, Cleary P, Saveljeva S, Samali A (2013) New directions in ER stressinduced cell death. Apoptosis 18: 537-546. [Crossref]

173. Rajamohan SB, Pillai VB, Gupta M, Sundaresan NR, Birukov KG, et al. (2009) SIRT1 promotes cell survival under stress by deacetylation-dependent deactivation of poly(ADP-ribose) polymerase 1. Mol Cell Biol 29: 4116-4129. [Crossref]

174. Fulda S, Gorman AM, Hori O, Samali A (2010) Cellular stress responses: cell survival and cell death. Int J Cell Biol 2010: 214074. [Crossref]

175. Wang Z, Moran E, Ding L, Cheng R, Xu X, Ma J (2014) PPARa regulates mobilization and homing of endothelial progenitor cells through the HIF-1a/SDF-1 pathway. Invest Ophthalmol Vis Sci 55: 3820-3832. [Crossref]

176. Moran EP, Ma JX (2015) Therapeutic Effects of PPAR $\alpha$ on Neuronal Death and Microvascular Impairment. PPAR Res 2015: 595426. [Crossref]

177. Boyle J. Molecular biology of the cell, 5th edition by B. Alberts, A. Johnson, J. Lewis, M. Raff, K. Roberts, and P. Walter. Garland Sciences, 2008: 1-1392.
178. Green DR, Galluzzi L, Kroemer G (2014) Cell biology. Metabolic control of cell death. Science 345: 1250256. [Crossref]

179. Epel ES, Blackburn EH, Lin J, Dhabhar FS, Adler NE, et al. (2004) Accelerated telomere shortening in response to life stress. Proc Natl Acad Sci U S A 101: 1731217315. [Crossref]

180. West AP, Shadel GS, Ghosh S (2011) Mitochondria in innate immune responses. Nat Rev Immunol 11: 389-402. [Crossref]

181. Festjens N, Vanden Berghe T, Vandenabeele P (2006) Necrosis, a well-orchestrated form of cell demise: Signalling cascades, important mediators and concomitant immune response. Biochim Biophys Acta - Bioenerg 1757: 1371-1387. [Crossref]

182. Poli G, Leonarduzzi G, Biasi F, Chiarpotto E (2004) Oxidative stress and cell signalling. Curr Med Chem 11: 1163-1182. [Crossref]

183. Sundar IK, Caito S, Yao H, Rahman I (2010) Oxidative stress, thiol redox signaling methods in epigenetics. Methods Enzymol 474: 213-244. [Crossref]

184. Bayeva M, Gheorghiade M, Ardehali H (2013) Mitochondria as a therapeutic target in heart failure. J Am Coll Cardiol 61: 599-610. [Crossref]

185. Yancey DM, Guichard JL, Ahmed MI, Zhou L, Murphy MP, et al. (2015) Cardiomyocyte mitochondrial oxidative stress and cytoskeletal breakdown in the heart with a primary volume overload. Am J Physiol Heart Circ Physiol 308: H651-663. [Crossref]

186. Mandelker L (2008) Introduction to oxidative stress and mitochondrial dysfunction. Vet Clin North Am Small Anim Pract 38: 1-30, v.[Crossref]

187. Naviaux RK (2012) Oxidative shielding or oxidative stress? J Pharmacol Exp Ther 342: 608-618. [Crossref]

188. Andersen JK (2004) Oxidative stress in neurodegeneration: cause or consequence? Nat Med 10: S18-25. [Crossref]

189. Corbi G, Conti V, Russomanno G, Longobardi G, Furgi G, et al. (2013) Adrenergic signaling and oxidative stress: a role for sirtuins? Front Physiol 4: 324. [Crossref]

190. Bauer ME, De la Fuente M. Oxidative Stress, Inflammaging, and Immunosenescence. Inflammation, Advancing Age and Nutrition: Research and Clinical Interventions. Elsevier, 2013: 39-47.

191. Matzinger P (1998) An innate sense of danger. Semin Immunol 10: 399-415. [Crossref]

192. Gallucci S, Lolkema M, Matzinger P (1999) Natural adjuvants: endogenous activators of dendritic cells. Nat Med 5: 1249-1255. [Crossref]

193. Maslanik T, Mahaffey L, Tannura K, Beninson L, Greenwood BN, et al. (2013) The inflammasome and danger associated molecular patterns (DAMPs) are implicated in cytokine and chemokine responses following stressor exposure. Brain Behav Immun 28: 54-62. [Crossref]

194. Tsuchiya K, Hara H (2014) The inflammasome and its regulation. Crit Rev Immunol 34: 41-80. [Crossref]

195. de Haan JJ, Smeets MB, Pasterkamp G, Arslan F (2013) Danger signals in the initiation of the inflammatory response after myocardial infarction. Mediators Inflamm 2013: 206039. [Crossref]

196. Petra AI, Panagiotidou S, Hatziagelaki E, Stewart JM, Conti P, et al. (2015) Gutmicrobiota-brain axis and its effect on neuropsychiatric disorders with suspected immune dysregulation. Clin Ther 37: 984-995. [Crossref]

197. Mizumori SJ, Jo YS (2013) Homeostatic regulation of memory systems and adaptive decisions. Hippocampus 23: 1103-1124. [Crossref]

198. McDonald RJ, Hong NS (2013) How does a specific learning and memory system in the mammalian brain gain control of behavior? Hippocampus 23: 1084-1102. [Crossref]

199. Naviaux RK (2014) Metabolic features of the cell danger response. Mitochondrion 16: 7-17. [Crossref]

200. Iwata M, Ota KT, Duman RS (2013) The inflammasome: pathways linking psychological stress, depression, and systemic illnesses. Brain Behav Immun 31: 105 114. [Crossref]

201. Chen JH, Simmons CA (2011) Cell-matrix interactions in the pathobiology of calcific aortic valve disease: critical roles for matricellular, matricrine, and matrix mechanics cues. Circ Res 108: 1510-1524. [Crossref]

202. Collins C, Osborne LD, Guilluy C, Chen Z, O'Brien ET 3rd, et al. (2014) Haemodynamic and extracellular matrix cues regulate the mechanical phenotype and stiffness of aortic endothelial cells. Nat Commun 5: 3984. [Crossref] 
203. Osidak MS, Osidak EO, Akhmanova MA, Domogatsky SP, Domogatskaya AS (2015) Fibrillar, fibril-associated and basement membrane collagens of the arterial wall: architecture, elasticity and remodeling under stress. Curr Pharm Des 21: 1124-1133. [Crossref]

204. Zhu J, Clark RA (2014) Fibronectin at select sites binds multiple growth factors and enhances their activity: expansion of the collaborative ECM-GF paradigm. $J$ Invest Dermatol 134: 895-901. [Crossref]

205. Head BP, Patel HH, Insel PA (2014) Interaction of membrane/lipid rafts with the cytoskeleton: impact on signaling and function: membrane/lipid rafts, mediators of cytoskeletal arrangement and cell signaling. Biochim Biophys Acta 1838: 532-545. [Crossref]

206. Daly KA, Liu S, Agrawal V, Brown BN, Johnson S a., et al. (2012) Damage associated molecular patterns within xenogeneic biologic scaffolds and their effects on host remodeling. Biomaterials 33: 91-101. [Crossref]

207. Ruvolo G, Pisano C, Candore G, Lio D, Palmeri C, et al. (2014) Can the TLR-4 mediated signaling pathway be "a key inflammatory promoter for sporadic TAA"? Mediators Inflamm 2014: 349476. [Crossref]

208. Nastase MV, Young MF, Schaefer L (2012) Biglycan: a multivalent proteoglycan providing structure and signals. J Histochem Cytochem 60: 963-975. [Crossref]

209. Imanaka-Yoshida K, Aoki H2 (2014) Tenascin-C and mechanotransduction in the development and diseases of cardiovascular system. Front Physiol 5: 283. [Crossref]

210. Piccinini AM, Midwood KS (2012) Endogenous control of immunity against infection: tenascin-C regulates TLR4-mediated inflammation via microRNA-155. Cell Rep 2: 914-926. [Crossref]

211. Zhao W, Zhao T, Chen Y, Ahokas RA, Sun Y (2008) Oxidative stress mediates cardiac fibrosis by enhancing transforming growth factor-beta1 in hypertensive rats. Mol Cell Biochem 317: 43-50. [Crossref]

212. Hirunsai M, Srikuea R, Yimlamai T (2015) Heat stress promotes extracellular matrix remodelling via TGF- $\beta 1$ and MMP-2/TIMP- 2 modulation in tenotomised soleus and plantaris muscles. Int J Hyperthermia 31: 336-348. [Crossref]

213. Wang YN, Sanders JE (2003) How does skin adapt to repetitive mechanical stress to become load tolerant? Med Hypotheses 61: 29-35. [Crossref]

214. Yamamoto K, Murphy G, Troeberg L (2015) Regulation of metalloproteinases in the extracellular environment: Emerging concepts. Matrix Biol 44-46C: 255-263. [Crossref]

215. Chen Q, Jin M, Yang F, Zhu J, Xiao Q, Zhang L (2013) Matrix metalloproteinases: Inflammatory regulators of cell behaviors in vascular formation and remodeling. Mediators Inflamm 2013: 928315. [Crossref]

216. Sternlicht MD, Werb Z (2001) How matrix metalloproteinases regulate cell behavior. Annu Rev Cell Dev Biol 17: 463-516. [Crossref]

217. Manicone AM, McGuire JK (2008) Matrix metalloproteinases as modulators of inflammation. Semin Cell Dev Biol 19: 34-41.[Crossref]

218. Page-McCaw A, Ewald AJ, Werb Z (2007) Matrix metalloproteinases and the regulation of tissue remodelling. Nat Rev Mol Cell Biol 8: 221-233. [Crossref]

219. Alie N, Eldib M, Fayad ZA, Mani V1 (2015) Inflammation, atherosclerosis, and coronary artery disease: PET/CT for the evaluation of atherosclerosis and inflammation. Clin Med Insights Cardiol 8: 13-21. [Crossref]

220. Wheeler-Jones CP (2005) Cell signalling in the cardiovascular system: an overview. Heart 91: 1366-1374. [Crossref]

221. Beninson LA, Brown PN, Loughridge AB, Saludes JP, Maslanik T, et al. (2014) Acute stressor exposure modifies plasma exosome-associated heat shock protein 72 (Hsp72) and microRNA (miR-142-5p and miR-203). PLoS One 9: e108748. [Crossref]

222. Thaker PH, Lutgendorf SK, Sood AK (2007) The neuroendocrine impact of chronic stress on cancer. Cell Cycle 6: 430-433. [Crossref]

223. Mendell JT, Olson EN (2012) MicroRNAs in stress signaling and human disease. Cell 148: 1172-87[Crossref]

224. Wang Y, Cui J, Sun X, Zhang Y (2011) Tunneling-nanotube development in astrocytes depends on 553 activation. Cell Death Differ 18: 732-742. [Crossref]

225. Abounit S, Zurzolo C (2012) Wiring through tunneling nanotubes--from electrical signals to organelle transfer. J Cell Sci 125: 1089-1098. [Crossref]

226. Austefjord MW, Gerdes HH, Wang X (2014) Tunneling nanotubes: Diversity in morphology and structure. Commun Integr Biol 7: e27934. [Crossref]
227. Sarafraz-Yazdi E (2014) Tunneling nanotubes: novel potentials for old players. Transl Res 164: 357-358. [Crossref]

228. Thayanithy V, Dickson EL, Steer C, Subramanian S, Lou E (2014) Tumor-stromal cross talk: direct cell-to-cell transfer of oncogenic microRNAs via tunneling nanotubes. Transl Res 164: 359-365. [Crossref]

229. Wang X, Gerdes HH (2012) Long-distance electrical coupling via tunneling nanotubes. Biochim Biophys Acta 1818: 2082-2086. [Crossref]

230. Agnati LF, Guidolin D, Maura G, Marcoli M, Leo G, et al. (2014) Information handling by the brain: proposal of a new 'paradigm' involving the roamer type of volume transmission and the tunneling nanotube type of wiring transmission. $J$ Neural Transm 121: 1431-1449. [Crossref]

231. Marzo L, Gousset K, Zurzolo C (2012) Multifaceted roles of tunneling nanotubes in intercellular communication. Front Physiol 3: 72. [Crossref]

232. Minuth WW, Denk L (2015) When morphogenetic proteins encounter special extracellular matrix and cell-cell connections at the interface of the renal stem/ progenitor cell niche. Anat Cell Biol 48: 1-9. [Crossref]

233. Bloemendal S, Kück U (2013) Cell-to-cell communication in plants, animals, and fungi: a comparative review. Naturwissenschaften 100: 3-19. [Crossref]

234. Simard SW, Durall DM (2004) Mycorrhizal networks: a review of their extent, function, and importance. Can J Bot 82: 1140-1165.

235. Teste FP, Simard SW (2008) Mycorrhizal networks and distance from mature trees alter patterns of competition and facilitation in dry Douglas-fir forests. Oecologia 158: 193-203. [Crossref]

236. Selosse MA, Richard F, He X, Simard SW (2006) Mycorrhizal networks: des liaisons dangereuses? Trends Ecol Evol 21: 621-628. [Crossref]

237. Scrivo R, Vasile M, Bartosiewicz I, Valesini G (2011) Inflammation as "common soil" of the multifactorial diseases. Autoimmun Rev 10: 369-374. [Crossref]

238. Spiers JG, Chen HJ, Sernia C, Lavidis NA (2015) Activation of the hypothalamicpituitary-adrenal stress axis induces cellular oxidative stress. Front Neurosci 8: 456. [Crossref]

239. Chen HJ, Spiers JG, Sernia C, Lavidis NA (2015) Response of the nitrergic system to activation of the neuroendocrine stress axis. Front Neurosci 9: 3. [Crossref]

240. Joseph-Bravo P, Jaimes-Hoy L, Charli JL (2015) Regulation of TRH neurons and energy homeostasis-related signals under stress. J Endocrinol 224: R139-159. [Crossref]

241. Iguchi Y, Kosugi S, Nishikawa H, Lin Z, Minabe Y, et al. (2014) Repeated exposure of adult rats to transient oxidative stress induces various long-lasting alterations in cognitive and behavioral functions. PLoS One 9: e114024. [Crossref]

242. Reynolds RM, Labad J, Buss C, Ghaemmaghami P, Räikkönen K (2013) Transmitting biological effects of stress in utero: implications for mother and offspring. Psychoneuroendocrinology 38: 1843-1849. [Crossref]

243. Brunton PJ (2013) Effects of maternal exposure to social stress during pregnancy: consequences for mother and offspring. Reproduction 146: R175-189. [Crossref]

244. Portaluppi F (2014) The circadian organization of the cardiovascular system in health and disease. Indian J Exp Biol 52: 395-398. [Crossref]

245. Foster RG, Roenneberg T (2008) Human responses to the geophysical daily, annual and lunar cycles. Curr Biol 18: R784-784R794. [Crossref]

246. Packer C, Swanson A, Ikanda D, Kushnir H (2011) Fear of darkness, the full moon and the nocturnal ecology of African lions. PLoS One 6: e22285. [Crossref]

247. Zimecki M (2006) The lunar cycle: effects on human and animal behavior and physiology. Postepy Hig Med Dosw 60: 1-7. [Crossref]

248. Cajochen C, Altanay-Ekici S, Münch M, Frey S, Knoblauch V, et al. (2013) Evidence that the lunar cycle influences human sleep. Curr Biol 23: 1485-1488. [Crossref]

249. Masaoka Y, Izumizaki M, Homma I2 (2014) Where is the rhythm generator for emotional breathing? Prog Brain Res 209: 367-377. [Crossref]

250. Homma I, Masaoka Y (2008) Breathing rhythms and emotions. Exp Physiol 93: 1011 1021. [Crossref]

251. Voinescu BI (2009) Clock genes, chronotypes and diseases. Hum Vet Med 1: 19-35.

252. Buzsáki G, Watson BO (2012) Brain rhythms and neural syntax: implications for efficient coding of cognitive content and neuropsychiatric disease. Dialogues Clin Neurosci 14: 345-367. [Crossref] 
253. Levine JH, Lin Y, Elowitz MB (2013) Functional roles of pulsing in genetic circuits. Science 342: 1193-1200. [Crossref]

254. Peek CB, Affinati AH, Ramsey KM, Kuo HY, Yu W, et al. (2013) Circadian clock $\mathrm{NAD}+$ cycle drives mitochondrial oxidative metabolism in mice. Science 342 : 1243417. [Crossref]

255. Vriend J, Reiter RJ (2015) Melatonin feedback on clock genes: a theory involving the proteasome. J Pineal Res 58: 1-11. [Crossref]

256. Fu L, Kettner NM (2013) The circadian clock in cancer development and therapy. Prog Mol Biol Transl Sci 119: 221-282. [Crossref]

257. Borjigin J, Zhang LS, Calinescu AA (2012) Circadian regulation of pineal gland rhythmicity. Mol Cell Endocrinol 349: 13-19. [Crossref]

258. Nivala M, Ko CY, Nivala M, Weiss JN, Qu Z (2013) The emergence of subcellular pacemaker sites for calcium waves and oscillations. J Physiol 591: 5305-5320. [Crossref]

259. Clement CA, Kristensen SG, Møllgård K, Pazour GJ, Yoder BK, et al. (2009) The primary cilium coordinates early cardiogenesis and hedgehog signaling in cardiomyocyte differentiation. J Cell Sci 122: 3070-3082. [Crossref]

260. Mitchison HM, Schmidts M, Loges NT, Freshour J, Dritsoula A, et al. (2012) Mutations in axonemal dynein assembly factor DNAAF3 cause primary ciliary dyskinesia. Nat Genet 44: 381-9, S1-2. [Crossref]

261. Maury E, Ramsey KM, Bass J (2010) Circadian rhythms and metabolic syndrome: from experimental genetics to human disease. Circ Res 106: 447-462. [Crossref]

262. Wulff K, Joyce E (2011) Circadian rhythms and cognition in schizophrenia. Br J Psychiatry 198: 250-252. [Crossref]

263. Muehsam D, Ventura C (2014) Life rhythm as a symphony of oscillatory patterns: electromagnetic energy and sound vibration modulates gene expression for biological signaling and healing. Glob Adv Health Med 3: 40-55. [Crossref]

264. Ferrell JE Jr, Tsai TY, Yang Q (2011) Modeling the cell cycle: why do certain circuits oscillate? Cell 144: 874-885. [Crossref]

265. Glass L (2001) Synchronization and rhythmic processes in physiology. Nature 410: 277-284. [Crossref]

266. Bordyugov G, Westermark PO, Korenčič A, Bernard S, Herzel H (2013) Mathematical modeling in chronobiology. Handb Exp Pharmacol : 335-357. [Crossref]

267. Lara-Aparicio M, Barriga-Montoya C, Padilla-Longoria P, Fuentes-Pardo B (2014) Modeling some properties of circadian rhythms. Math Biosci Eng 11: 317-330. [Crossref]

268. Dodla R, Wilson CJ (2013) Interaction function of oscillating coupled neurons. Phys Rev E Stat Nonlin Soft Matter Phys 88: 042704. [Crossref]

269. Martens EA, Thutupalli S, Fourrière A, Hallatschek O (2013) Chimera states in mechanical oscillator networks. Proc Natl Acad Sci U S A 110: 10563-10567. [Crossref]

270. Milyaev VA, Binhi VN (2007) On the physical nature of magnetobiological effects. Quantum Electron 36: 691-701.

271. Machlup S (2007) Ion parametric resonance: resolving the signal-to-noise-ratio paradox. Electromagn Biol Med 26: 251-256. [Crossref]

272. Chee HK, Yang JS, Joung JG, Zhang BT, Oh SJ (2015) Characteristic molecular vibrations of adenosine receptor ligands. FEBS Lett 589: 548-552. [Crossref]

273. Bose B (2013) Systems biology: a biologist's viewpoint. Prog Biophys Mol Biol 113: 358-368. [Crossref]

274. Karplus M, Petsko GA (1990) Molecular dynamics simulations in biology. Nature 347: 631-639. [Crossref]

275. Alberghina L, Cirulli C (2010) Proteomics and systems biology to tackle biological complexity: Yeast as a case study. Proteomics 10: 4337-4341. [Crossref]

276. Ruch RJ (2002) Intercellular communication, homeostasis, and toxicology. Toxicol Sci 68: 265-266. [Crossref]

277. Trosko JE, Chang CC, Upham B, Wilson M (1998) Epigenetic toxicology as toxicant-induced changes in intracellular signalling leading to altered gap junctional intercellular communication. Toxicol Lett 102-103: 71-78. [Crossref]

278. Seegers JC, Engelbrecht CA, van Papendorp DH (2001) Activation of signaltransduction mechanisms may underlie the therapeutic effects of an applied electric field. Med Hypotheses 57: 224-230. [Crossref]
279. Hill BG, Dranka BP, Bailey SM, Lancaster JR Jr, Darley-Usmar VM (2010) What part of NO don't you understand? Some answers to the cardinal questions in nitric oxide biology. J Biol Chem 285: 19699-19704. [Crossref]

280. Illi B, Dello Russo C, Colussi C, Rosati J, Pallaoro M, et al. (2008) Nitric oxide modulates chromatin folding in human endothelial cells via protein phosphatase $2 \mathrm{~A}$ activation and class II histone deacetylases nuclear shuttling. Circ Res 102: 51-58. [Crossref]

281. Batchelor AM, Bartus K, Reynell C, Constantinou S, Halvey EJ, et al. (2010) Exquisite sensitivity to subsecond, picomolar nitric oxide transients conferred on cells by guanylyl cyclase-coupled receptors. Proc Natl Acad Sci U S A 107: 22060-22065. [Crossref]

282. Mayrovitz HN, Groseclose EE (2005) Effects of a static magnetic field of either polarity on skin microcirculation. Microvasc Res 69: 24-27. [Crossref]

283. Mayrovitz HN, Groseclose EE, Markov M, Pilla AA (2001) Effects of permanent magnets on resting skin blood perfusion in healthy persons assessed by laser Doppler flowmetry and imaging. Bioelectromagnetics 22: 494-502. [Crossref]

284. McKay JC, Prato FS, Thomas AW (2007) A literature review: the effects of magnetic field exposure on blood flow and blood vessels in the microvasculature. Bioelectromagnetics 28: 81-98. [Crossref]

285. Pan Y, Dong Y, Hou W, Ji Z, Zhi K, et al. (2013) Effects of PEMF on microcirculation and angiogenesis in a model of acute hindlimb ischemia in diabetic rats. Bioelectromagnetics 34: 180-188. [Crossref]

286. Tepper OM, Callaghan MJ, Chang EI, Galiano RD, Bhatt KA, et al. (2004) Electromagnetic fields increase in vitro and in vivo angiogenesis through endothelial release of FGF-2. FASEB J 18: 1231-1213. [Crossref]

287. Reale M, De Lutiis MA, Patruno A, Speranza L, Felaco M, et al. (2006) Modulation of MCP-1 and iNOS by $50-\mathrm{Hz}$ sinusoidal electromagnetic field. Nitric Oxide 15: 5057. [Crossref]

288. Kim SS, Shin HJ, Eom DW, Huh JR, Woo Y, et al. (2002) Enhanced expression of neuronal nitric oxide synthase and phospholipase C-gammal in regenerating murine neuronal cells by pulsed electromagnetic field. Exp Mol Med 34: 53-59. [Crossref]

289. Pilla AA (2012) Electromagnetic fields instantaneously modulate nitric oxide signaling in challenged biological systems. Biochem Biophys Res Commun 426: 330 333. [Crossref]

290. Lancellotti P, Nchimi A, Delierneux C, Hego A, Gosset C, et al. (2015) biological effects of cardiac magnetic resonance on human blood cells. Circ Cardiovasc Imaging 8: e003697. [Crossref]

291. Feynman Richard. The Feynman Lectures on Physics Volume 3. 1970.

292. Greene B.L'universo elegante. Superstringhe, dimensioni nascoste e la ricerca della teoria ultima. Einaudi 2008.

293. Greene B. La trama del cosmo. Spazio, tempo, realtà. Einaudi 2006.

294. Bottaccioli F. Geni e Comportamenti - Scienza e Arte della Vita. Red Ed.;2009: 144-5

295. Barabási AL, Oltvai ZN (2004) Network biology: understanding the cell's functional organization. Nat Rev Genet 5: 101-113. [Crossref]

296. Foffi G, Pastore A, Piazza F, Temussi PA (2013) Macromolecular crowding: chemistry and physics meet biology (Ascona, Switzerland, 10-14 June 2012). Phys Biol 10: 040301. [Crossref]

297. Arndt M, Juffmann T, Vedral V (2009) Quantum physics meets biology. HFSP J 3 386-400. [Crossref]

298. West BJ (2014) A mathematics for medicine: The Network Effect. Front Physiol 5 : 456. [Crossref]

299. Adak A, Robinson AP, Singh PK, Chatterjee G, Lad AD, et al. (2015) Terahertz acoustics in hot dense laser plasmas. Phys Rev Lett 114: 115001. [Crossref]

300. Manoli G, Bonetti S, Domec JC, Putti M, Katul G, et al. (2014) Tree root systems competing for soil moisture in a 3D soil-plant model. Adv Water Resour 66: 32-42.

301. Fagherazzi S, Bortoluzzi A, Dietrich WE, Adami A, Lanzoni S, et al. (1999) Tidal networks 1. Automatic network extraction and preliminary scaling features from digital terrain maps. Water Resour Res 35: 3891-3904.

302. Rinaldo A, Fagherazzi S, Lanzoni S, Marani M, Dietrich WE (1999) Tidal networks 2. Watershed delineation and comparative network morphology. Water Resour Res 35: 3905-3917. Crossref]

303. Combariza ME, Yu X, Nesbitt WS, Mitchell A, Tovar-Lopez FJ (2015) Nonlinear 
Dynamic Modelling of Platelet Aggregation via Microfluidic Devices. IEEE Trans Biomed Eng 62: 1718-1727. [Crossref]

304. Bashan A, Bartsch RP, Kantelhardt JW, Havlin S, Ivanov PCh (2012) Network physiology reveals relations between network topology and physiological function. Nat Commun 3: 702. [Crossref]

305. Mikulecky DC (1996) Complexity, communication between cells, and identifying the functional components of living systems: some observations. Acta Biotheor 44: 179208. [Crossref]

306. Philippe P, Mansi O (1998) Nonlinearity in the epidemiology of complex health and disease processes. Theor Med Bioeth 19: 591-607. [Crossref]

307. Higgins JP (2002) Nonlinear systems in medicine. Yale J Biol Med 75: 247-260. [Crossref]

308. Horgan J (1995) From Complexity to Perplexity. Sci Am 272: 104-109.

309. Aird WC (2002) Endothelial cell dynamics and complexity theory. Crit Care Med 30: S180-185. [Crossref]

310. Pezard L, Nandrino JL (2001). Dynamic paradigm in psychopathology: "chaos theory", from physics to psychiatry. Encephale 27: 260-268. [Crossref]

311. Guarini G (1993) New horizons in medicine. Chaos and its laws. Recenti Prog Med 84: 278-286. [Crossref]

312. Guarini G, Onofri E (1993) New horizons in medicine. Complexity and predictability in internal medicine. Recenti Prog Med 84: 691-697. [Crossref]

313. Guarini G (1994) New horizons in medicine. Aging and the laws of modern physics. Recenti Prog Med 85: 32-36. [Crossref]

314. Elbert T, Ray WJ, Kowalik ZJ, Skinner JE, Graf KE, et al. (1994) Chaos and physiology: deterministic chaos in excitable cell assemblies. Physiol Rev 74: 1-47. [Crossref]

315. Auffray C, Nottale L (2008) Scale relativity theory and integrative systems biology: 1. Founding principles and scale laws. Prog Biophys Mol Biol 97: 79-114. [Crossref]

316. Nottale L, Auffray C (2008) Scale relativity theory and integrative systems biology: 2. Macroscopic quantum-type mechanics. Prog Biophys Mol Biol 97: 115-157. [Crossref]

317. Dada JO, Mendes P (2011) Multi-scale modelling and simulation in systems biology. Integr Biol (Camb) 3: 86-96. [Crossref]

318. Thaheld FH (2005) An interdisciplinary approach to certain fundamental issues in the fields of physics and biology: towards a unified theory. Biosystems 80: 41-56. [Crossref]

319. Antonucci TC, Webster NJ (2014) Rethinking Cells to Society. Res Hum Dev 11: 309-322. [Crossref]

320. Başar E, Güntekin B (2007) A breakthrough in neuroscience needs a "Nebulous Cartesian System" Oscillations, quantum dynamics and chaos in the brain and vegetative system. Int J Psychophysiol 64: 108-122. [Crossref]

321. Braun DA, Ortega PA, Wolpert DM (2009) Nash equilibria in multi-agent motor interactions. PLoS Comput Biol 5: e1000468. [Crossref]

322. Trapa PE, Nowak MA (2000) Nash equilibria for an evolutionary language game. $J$ Math Biol 41: 172-188. [Crossref]

323. Hofbauer J (2005) From Nash and Brown to Maynard Smith: Equilibria, Dynamics and ESS. Selection 1: 81-88.

324. Hart S (2011) Commentary: Nash equilibrium and dynamics. Games Econ Behav 71: 6-8.

325. Hart S, Mas-Colell A (2006) Stochastic uncoupled dynamics and Nash equilibrium. Games Econ Behav 57: 286-303.

326. Frihauf P, Krstic M, Basar T (2011)Nash equilibrium seeking for dynamic systems with non-quadratic payoffs. In: IFAC Proceedings Volumes (IFAC-PapersOnline): 3605-3610.

327. Bayati M, Borgs C, Braunstein A, Chayes J, Ramezanpour A, et al. (2008) Statistical mechanics of steiner trees. Phys Rev Lett 101: 037208. [Crossref]

328. Tuncbag N, Braunstein A, Pagnani A, Huang SSC, Chayes J, et al. (2012) Simultaneous reconstruction of multiple signaling pathways via the prize-collecting steiner forest problem. In: Lecture Notes in Computer Science (including subseries Lecture Notes in Artificial Intelligence and Lecture Notes in Bioinformatics) 287-301.
329. Hu Z, Yang RC (2013) A new distribution-free approach to constructing the confidence region for multiple parameters. PLoS One 8: e81179. [Crossref]

330. Muldoon MF, Bachen EA, Manuck SB, Waldstein SR, Bricker PL, et al. (1992) Acute cholesterol responses to mental stress and change in posture. Arch Intern Med 152: 775-780. [Crossref]

331. Wirtz PH, Ehlert U, Bärtschi C, Redwine LS, von Känel R (2009) Changes in plasma lipids with psychosocial stress are related to hypertension status and the norepinephrine stress response. Metabolism 58: 30-37. [Crossref]

332. Martin EA, Prasad A, Rihal CS, Lerman LO, Lerman A (2010) Endothelial function and vascular response to mental stress are impaired in patients with apical ballooning syndrome. J Am Coll Cardiol 56: 1840-1846. [Crossref]

333. Steptoe A, Brydon L (2005) Associations between acute lipid stress responses and fasting lipid levels 3 years later. Health Psychol 24: 601-607. [Crossref]

334. Dockray S, Steptoe A (2010) Positive affect and psychobiological processes. Neurosci Biobehav Rev 35: 69-75. [Crossref]

335. Liebetrau C, Nef HM, Hamm CW (2014) Troponin: more lessons to learn. Eur Heart J 35: 338-340. [Crossref]

336. McCormack J, Vandermeer B, Allan GM (2013) How confidence intervals become confusion intervals. BMC Med Res Methodol 13: 134. [Crossref]

337. Giustiniano E, Meco M (2014) Clinicians have not to use trials like drunks do with street lamps. J Integr Cardiol 1: 7-7.

338. Giannoni A, Baruah R, Leong T, Rehman MB, Pastormerlo LE, et al. (2014) Do optimal prognostic thresholds in continuous physiological variables really exist? Analysis of origin of apparent thresholds, with systematic review for peak oxygen consumption, ejection fraction and BNP. PLoS One 9: e 81699. [Crossref]

339. Romanoski CE, Glass CK, Stunnenberg HG, Wilson L, Almouzni G (2015) Epigenomics: Roadmap for regulation. Nature 518: 314-316. [Crossref]

340. El-Hani CN (2007) Between the cross and the sword: The crisis of the gene concept. Genet Mol Biol 30: 297-307.

341. Huang SS, Fraenkel E (2009) Integrating proteomic, transcriptional, and interactome data reveals hidden components of signaling and regulatory networks. Sci Signal 2 ra40. [Crossref]

342. Rhee EP, Gerszten RE (2012) Metabolomics and cardiovascular biomarker discovery. Clin Chem 58: 139-147. [Crossref]

343. Nicholson JK, Holmes E, Elliott P (2008) The metabolome-wide association study: a new look at human disease risk factors. J Proteome Res 7: 3637-3638. [Crossref]

344. Holmes E, Nicholson JK (2007) Human metabolic phenotyping and metabolome wide association studies. Ernst Schering Found Symp Proc : 227-249. [Crossref]

345. Caspi A, Hariri AR, Holmes A, Uher R, Moffitt TE (2010) Genetic sensitivity to the environment: the case of the serotonin transporter gene and its implications for studying complex diseases and traits. Am J Psychiatry 167: 509-527. [Crossref]

346. Gapp K, von Ziegler L, Tweedie-Cullen RY, Mansuy IM (2014) Early life epigenetic programming and transmission of stress-induced traits in mammals: how and when can environmental factors influence traits and their transgenerational inheritance? Bioessays 36: 491-502

347. Zaidi SK, Young DW, Montecino M, van Wijnen AJ, Stein JL, et al. (2011) Bookmarking the genome: maintenance of epigenetic information. J Biol Chem 286 18355-18361. [Crossref]

348. Fang L, Wuptra K, Chen D, Li H, Huang SK, et al. (2014) Environmental-stressinduced Chromatin Regulation and its Heritability. J Carcinog Mutagen 5. [Crossref]

349. Fahrner JA, Bjornsson HT (2014) Mendelian disorders of the epigenetic machinery: tipping the balance of chromatin states. Annu Rev Genomics Hum Genet 15: 269-293. [Crossref]

350. Liebers R, Rassoulzadegan M, Lyko F (2014) Epigenetic regulation by heritable RNA. PLoS Genet 10: e1004296. [Crossref]

351. Wang X, Gulbahce N, Yu H (2011) Network-based methods for human disease gene prediction. Brief Funct Genomics 10: 280-293. [Crossref]

352. Ogbuanu IU, Zhang H, Karmaus W (2009) Can we apply the Mendelian randomization methodology without considering epigenetic effects? Emerg Themes Epidemiol 6: 3.

353. Christians ES, Mustafi SB, Benjamin IJ1 (2014) Chaperones and cardiac misfolding protein diseases. Curr Protein Pept Sci 15: 189-204. [Crossref] 
354. Christians ES, Benjamin IJ (2012) Proteostasis and REDOX state in the heart. Am J Physiol Heart Circ Physiol 302: H24-37. [Crossref]

355. Gitter A, Bar-Joseph Z (2013) Identifying proteins controlling key disease signaling pathways. Bioinformatics 29: i227-236. [Crossref]

356. Bailly-Bechet M, Borgs C, Braunstein A, Chayes J, Dagkessamanskaia A, et al. (2011) Finding undetected protein associations in cell signaling by belief propagation. Proc Natl Acad Sci U S A 108: 882-887. [Crossref]

357. Miyake K, Yang C, Minakuchi Y, Ohori K, Soutome M, et al. (2013) Comparison of Genomic and Epigenomic Expression in Monozygotic Twins Discordant for Rett Syndrome. PLoS One. [Crossref]

358. Lee C, Park KH, Cho M (2006) Vibrational dynamics of DNA. I. Vibrational basis modes and couplings. $J$ Chem Phys 125: 114508. [Crossref]

359. Lee C, Cho M (2006) Vibrational dynamics of DNA. II. Deuterium exchange effects and simulated IR absorption spectra. J Chem Phys 125: 114509. [Crossref]

360. Lee C, Park KH, Kim JA, Hahn S, Cho M (2006) Vibrational dynamics of DNA. III. Molecular dynamics simulations of DNA in water and theoretical calculations of the two-dimensional vibrational spectra. J Chem Phys 125: 114510. [Crossref]

361. Lee C, Cho M (2007) Vibrational dynamics of DNA: IV. Vibrational spectroscopic characteristics of A-, B-, and Z-form DNA's. J Chem Phys 126: 145102. [Crossref]

362. Meyl K (2012) DNA and cell resonance: magnetic waves enable cell communication. DNA Cell Biol 31: 422-426. [Crossref]

363. Meyl K (2012) Task of the introns, cell communication explained by field physics. $J$ Cell CommunSignal 6: 53-58. [Crossref]

364. Kotnala A, Wheaton S, Gordon R (2015) Playing the notes of DNA with light: extremely high frequency nanomechanical oscillations. Nanoscale 7: 2295-2300. [Crossref]

365. Martirosyan V, Baghdasaryan N, Ayrapetyan S (2013) The study of the effects of mechanical vibration at infrasound frequency on. [(3)H]-thymidine incorporation into DNA of E. coli K-12. Electromagn Biol Med 32: 40-47. [Crossref]

366. Oh ES, Seo YK, Yoon HH, Cho H, Yoon MY, et al. (2011) Effects of sub-sonic vibration on the proliferation and maturation of 3T3-L1 cells. Life Sci 88: 169-177. [Crossref]

367. Adair RK (2002) Vibrational resonances in biological systems at microwave frequencies. Biophys J 82: 1147-1152. [Crossref]

368. Roller EM, Khorashad LK, Fedoruk M, Schreiber R, Govorov AO, et al. (2015) DNA-assembled nanoparticle rings exhibit electric and magnetic resonances at visible frequencies. Nano Lett 15: 1368-1373. [Crossref]

369. Picard C, Davoust L (2007) Resonance frequencies of meniscus waves as a physical mechanism for aDNA biosensor. Langmuir 23: 1394-1402.

370. Rakyan VK, Preis J, Morgan HD, Whitelaw E (2001) The marks, mechanisms and memory of epigenetic states in mammals. Biochem J 356: 1-10. [Crossref]

371. Speybroeck L (2006) From Epigenesis to Epigenetics. Ann N Y Acad Sci 981: 61-81. [Crossref]

372. Gollogly L, Momen H (2006) Ethical dilemmas in scientific publication: pitfalls and solutions for editors. Rev Saude Publica 40 Spec no. [Crossref]

373. Seife C (2015) Research misconduct identified by the US Food and Drug Administration: out of sight, out of mind, out of the peer-reviewed literature. JAMA Intern Med 175: 567-577. [Crossref]

374. Seife C (2012) Is drug research trustworthy? The pharmaceutical industry funnels money to prominent scientists who are doing research that affects its products--and nobody can stop it. Sci Am 307: 56-63. [Crossref]

375. Benjamin DK Jr, Smith PB, Sun MJ, Murphy MD, Avant D, et al. (2009) Safety and transparency of pediatric drug trials. Arch Pediatr Adolesc Med 163: 1080-1086. [Crossref]

376. Menicanti L (2014) L'impianto transcatetere di valvola aortica tra illusioni e dati reali. G Ital Cardiol 15: 185-186.

377. RichS, Sheikh A, Gallastegui J, Kondos GT, Mason T, et al. (1982) Determination of left ventricular ejection fraction by visual estimation during real-time two-dimensional echocardiography. Am Heart $J$ 104: 603-606. [Crossref]

378. AmicoAF, Lichtenberg GS, Reisner SA, Stone CK, Schwartz RG, et al. (1989) Superiority of visual versus computerized echocardiographic estimation of radionuclide left ventricular ejection fraction. Am Heart J 118: 1259-1265. [Crossref]
379. Gopal AS, Shen Z, Sapin PM, Keller AM, Schnellbaecher MJ, et al. (1995) Assessment of cardiac function by three-dimensional echocardiography compared with conventional noninvasive methods. Circ 192: 842-853. [Crossref]

380. van Royen N, Jaffe CC, Krumholz HM, Johnson KM, Lynch PJ, et al. (1996) Comparison and reproducibility of visual echocardiographic and quantitative radionuclide left ventricular ejection fractions. Am J Cardiol 77: 843-850. [Crossref]

381. Hope MD, de la Pena E, Yang PC, Liang DH, McConnell MV, et al. (2003) A visual approach for the accurate determination of echocardiographic left ventricular ejection fraction by medical students. J Am Soc Echocardiogr 16: 824-831. [Crossref]

382. Sievers B, Kirchberg S, Franken U, Puthenveettil B-J, Bakan A, et al. (2005) Visual estimation versus quantitative assessment of left ventricular ejection fraction: a comparison by cardiovascular magnetic resonance imaging. Am Heart $J$ 150: 737742. [Crossref]

383. Bottaccioli F (2014) Epigenetica e psiconeuroendocrinoimmunologia. 1st ed. Milano Edra editore

384. Fani Marvasti F, Stafford RS (2012) From sick care to health care--reengineering prevention into the U.S. system. N Engl J Med 367: 889-891. [Crossref]

385. Frances AJ (2013) Saving Normal: An Insider's Revolt Against Out-Of-Control Psychiatric Diagnosis, DSM-5, Big Pharma, and the Medicalization of Ordinary Life 1st ed. New York: William Morrow \& Co 1-336.

386. Frances AJ. Antidepressant Use Has Gone Crazy: Bad News From the CDC Psychiatric Times. Psychiatr Times October 28, 2011.

387. Ridker PM, Cook NR (2013) Statins: new American guidelines for prevention of cardiovascular disease. Lancet 382: 1762-1765. [Crossref]

388. Ridker PM, Wilson PW (2013) A trial-based approach to statin guidelines. JAMA 310 1123-1124. [Crossref]

389. Cook NR, Ridker PM (2014) Response to Comment on the reports of over-estimation of ASCVD risk using the 2013 AHA/ACC risk equation. Circulation 129: 268-269. [Crossref]

390. Esserman LJ, Thompson IM, Jr, Reid B (2013) Overdiagnosis and overtreatment in cancer: An opportunity for improvement emerging overdiagnosis and overtreatmen viewpoint. JAMA J Am Med Assoc 310: 797-798. [Crossref]

391. Esserman LJ, Thompson IM, Reid B, Nelson P, Ransohoff DF, et al. (2014) Addressing overdiagnosis and overtreatment in cancer: a prescription for change. Lancet Oncol 15: e234-242. [Crossref]

392. Esserman L, Thompson I (2010) Solving the overdiagnosis dilemma. J Natl Cancer Inst 102: 582-583. [Crossref]

393. Morgan G, Ward R, Barton M (2004) The contribution of cytotoxic chemotherapy to 5-year survival in adult malignancies. Clin Oncol ( $R$ Coll Radiol) 16: 549-560. [Crossref]

394. Bobbio M, Galvagno G (2014) Nuove diagnosi senza nuovi trattamenti. G Ital Cardiol 15: 289-92.

395. Riaz IB, Husnain M, Riaz H, Asawaeer M4, Bilal J, et al. (2014) Meta-analysis of revascularization versus medical therapy for atherosclerotic renal artery stenosis. $\mathrm{Am}$ J Cardiol 114: 1116-1123. [Crossref]

396. BangaloreS, Pursnani S, Kumar S, Bagos PG (2013) Percutaneous coronary intervention versus optimal medical therapy for prevention of spontaneous myocardial infarction in subjects with stable ischemic heart disease. Circulation 127: 769-781. [Crossref]

397. ThomasS, Gokhale R, Boden WE, Devereaux PJ (2013) A meta-analysis of randomized controlled trials comparing percutaneous coronary intervention with medical therapy in stable angina pectoris. Can J Cardiol 29: 472-482. [Crossref]

398. BodenWE, O’Rourke RA, Teo KK, Maron DJ, Hartigan PM, et al. (2009) Impact of optimal medical therapy with or without percutaneous coronary intervention on longterm cardiovascular end points in patients with stable coronary artery disease (from the COURAGE Trial). Am J Cardiol 104: 1-4. [Crossref]

399. El-Hayek G, Messerli F, Bangalore S2, Hong MK, Herzog E, et al. (2014) Metaanalysis of randomized clinical trials comparing short-term versus long-term dua antiplatelet therapy following drug-eluting stents. Am J Cardiol 114: 236-242. [Crossref]

400. Brieger DB, Redfern J (2013) Contemporary themes in acute coronary syndrome management: from acute illness to secondary prevention. Med J Aust 199: 174-178. [Crossref] 
401. Moynihan R, Heath I, Henry D (2002) Selling sickness: the pharmaceutical industry and disease mongering. BMJ 324: 886-891. [Crossref]

402. Kravitz RL, Bell RA (2013) Media, messages, and medication: strategies to reconcile what patients hear, what they want, and what they need from medications. BMC Med Inform Decis Mak 13 Suppl 3: S5. [Crossref]

403. Angell M. The Truth About the Drug Companies. The New York Review of Books. July 15, 2004.

404. Angell M. The illusions of psychiatry. New York Rev Books,July 7, 201.

405. Angell M. The Epidemic of Mental Illness?: Why?? New York Rev Books,June 23, 2011.

406. Kassirer JP (2007) Commercialism and medicine: an overview. Camb Q Healthc Ethics 16: 377-386. [Crossref]

407. RyanTJ (2005) Dr Jerome Kassirer's Book On The Take: How Medicine's Complicity With Big Business Can Endanger Your Health: Worthy of Comment. Circulation 111: 2552-2554.

408. Smith R (2005) Medical journals are an extension of the marketing arm of pharmaceutical companies. PLoS Med 2: e138. [Crossref]

409. Engel GL (1977) The need for a new medical model: a challenge for biomedicine. Science 196: 129-136. [Crossref]

410. Lahm T, McCaslin CA, Wozniak TC, Ghumman W, Fadl YY, et al. (2010) Medical and surgical treatment of acute right ventricular failure. J Am Coll Cardiol 56: 14351446. [Crossref]

411. Jentzer JC, Coons JC, Link CB, Schmidhofer M (2015) Pharmacotherapy update on the use of vasopressors and inotropes in the intensive care unit. $J$ Cardiovasc Pharmacol Ther 20: 249-260. [Crossref]

412. EslerM, Kaye D (1998) Increased sympathetic nervous system activity and its therapeutic reduction in arterial hypertension, portal hypertension and heart failure. J Auton Nerv Syst 72: 210-9

413. Schömig A, Richardt G, Kurz T (1995) Sympatho-adrenergic activation of the ischemic myocardium and its arrhythmogenic impact. Herz 20: 169-186. [Crossref]

414. Zheng M, Han QD, Xiao RP (2004) Distinct beta-adrenergic receptor subtype signaling in the heart and their pathophysiological relevance. Sheng Li Xue Bao 56: 1-15. [Crossref]

415. Francis GS, Bartos JA, Adatya S (2014) Inotropes. J Am Coll Cardiol63: 2069-2078. [Crossref]

416. Schömig A (1990) Catecholamines in myocardial ischemia. Systemic and cardiac release. Circulation 82: II13-22. [Crossref]

417. Tank AW, Lee Wong D2 (2015) Peripheral and central effects of circulating catecholamines. ComprPhysiol 5: 1-15. [Crossref]

418. Woo AY, Xiao RP (2012) $\beta$-Adrenergic receptor subtype signaling in heart: from bench to bedside. Acta Pharmacol Sin 33: 335-341. [Crossref]

419. Cros C, Brette F (2013) Functional subcellular distribution of $\beta 1$ - and $\beta 2$-adrenergic receptors in rat ventricular cardiac myocytes. Physiol Rep 1: e00038. [Crossref]

420. Stiles GL, Strasser RH, Caron MG, Lefkowitz RJ (1983) Mammalian beta-adrenergic receptors. Structural differences in beta 1 and beta 2 subtypes revealed by peptide maps. J Biol Chem 258: 10689-10694. [Crossref]

421. BeauSL, Hand DE, Schuessler RB, Bromberg BI, Kwon B, et al. (2012) Relative densities of muscarinic cholinergic and beta-adrenergic receptors in the canine sinoatrial node and their relation to sites of pacemaker activity. Circ Res 77: 957-63. [Crossref]

422. Carrettiero DC, Ferrari MFR, Fior-Chadi DR (2012) a2-Adrenergic receptor distribution and density within the nucleus tractus solitarii of normotensive and hypertensive rats during development. Auton Neurosci 166: 39-46

423. Harris TJ, Waltman TJ, Carter SM, Maisel AS (1995) Effect of prolonged catecholamine infusion on immunoregulatory function: implications in congestive heart failure. J Am Coll Cardiol 26: 102-109. [Crossref]

424. Dünser MW, Hasibeder WR (2009) Sympathetic overstimulation during critical illness: adverse effects of adrenergic stress. J Intensive Care Med 24: 293-316. [Crossref]

425. Elenkov IJ, Wilder RL, Chrousos GP, Vizi ES (2000) The sympathetic nerve--an integrative interface between two supersystems: the brain and the immune system. Pharmacol Rev 52: 595-638. [Crossref
426. Vizi ES, Elenkov IJ (2002) Nonsynaptic noradrenaline release in neuro-immune responses. Acta BiolHung 53: 229-244. [Crossref]

427. Liao MH, Liu SS, Peng IC, Tsai FJ, Huang HH (2014) The stimulatory effects of alpha1-adrenergic receptors on TGF-beta, IGF-1 and hyaluronan production in human skin fibroblasts. Cell Tissue Res 357: 681-693. [Crossref]

428. Hanke ML, Powell ND, Stiner LM, Bailey MT, Sheridan JF (2012) Beta adrenergic blockade decreases the immunomodulatory effects of social disruption stress. Brain Behav Immun 26: 1150-1159. [Crossref]

429. Fu Q, Xu B, Liu Y, Parikh D, Li J, et al. (2014) Insulin inhibits cardiac contractility by inducing a Gi-biased $\beta 2$-adrenergic signaling in hearts. Diabetes 63: 2676-2689. [Crossref]

430. Rafatian N, Westcott KV, White RA, Leenen FH (2014) Cardiac macrophages and apoptosis after myocardial infarction: effects of central MR blockade. Am J Physiol Regul Integr Comp Physiol 307: R879-887. [Crossref]

431. Drobysheva A, Ahmad M, White R, Wang HW, Leenen FH (2013) Cardiac sympathetic innervation and PGP9.5 expression by cardiomyocytes after myocardial infarction: effects of central MR blockade. Am J Physiol Heart Circ Physiol 305: H1817-1829. [Crossref]

432. Kolmus K, Tavernier J2, Gerlo S3 (2015) B2-Adrenergic receptors in immunity and inflammation: stressing NF-kB. Brain Behav Immun 45: 297-310. [Crossref]

433. Chang CW, Lee L, Yu D, Dao K, Bossuyt J, et al. (2013) Acute $\beta$-adrenergic activation triggers nuclear import of histone deacetylase 5 and delays $\mathrm{G}(\mathrm{q})$-induced transcriptional activation. J Biol Chem 288: 192-204. [Crossref]

434. Sanders VM (2012) The beta2-adrenergic receptor on T and B lymphocytes: do we understand it yet? Brain Behav Immun 26: 195-200. [Crossref]

435. McAlees JW, Smith LT, Erbe RS, Jarjoura D, Ponzio NM, et al. (2011) Epigenetic regulation of beta2-adrenergic receptor expression in $\mathrm{T}(\mathrm{H}) 1$ and $\mathrm{T}(\mathrm{H}) 2$ cells. Brain Behav Immun 25: 408-415. [Crossref]

436. Murphree SS, Saffitz JE (1989) Distribution of beta-adrenergic receptors in failing human myocardium. Implications for mechanisms of down-regulation. Circulation 79: 1214-1225. [Crossref]

437. Weichert D, Kruse AC, Manglik A, Hiller C, Zhang C, et al. (2014) Covalent agonists for studying G protein-coupled receptor activation. Proc Natl Acad Sci U S A 111 : 10744-10748. [Crossref]

438. Martínez-LaordenE, García-Carmona J-A, Baroja-Mazo A, Romecín P, Atucha NM,et al (2014) Corticotropin-releasing factor (CRF) receptor-1 is involved in cardiac noradrenergic activity observed during naloxone-precipitated morphine withdrawal. Br J Pharmacol 2014;171: 688-700

439. Brodde OE, Bruck H, Leineweber K, Seyfarth T (2001) Presence, distribution and physiological function of adrenergic and muscarinic receptor subtypes in the human heart. Basic Res Cardiol 96: 528-538. [Crossref]

440. Somvanshi RK, Zou S, Qiu X, Kumar U (2014) Somatostatin receptor-2 negatively regulates $\beta$-adrenergic receptor mediated $\mathrm{Ca}(2+)$ dependent signaling pathways in H9c2 cells. Biochim Biophys Acta 1843: 735-45

441. Arioglu-Inan E, Ozakca I, Kayki-Mutlu G, Sepici-Dincel A, Altan VM (2013) The role of insulin-thyroid hormone interaction on $\hat{\mathrm{I}}^{2}$-adrenoceptor-mediated cardiac responses. Eur J Pharmacol 718: 533-543. [Crossref]

442. Sun J, Fu L, Tang X, Han Y, Ma D, et al. (2011) Testosterone modulation of cardiac $\hat{\mathrm{I}}^{2}$-adrenergic signals in a rat model of heart failure. Gen Comp Endocrinol 172: 518 525. [Crossref]

443. Shimoyama M, Ogino K, Furuse Y, Uchida K, Kinugasa Y, et al. (2001) Signaling pathway and chronotropic action of parathyroid hormone in isolated perfused rat heart. J Cardiovasc Pharmacol 38: 491-499. [Crossref]

444. Larson JE, Rainer PP, Watts VL, Yang R, Miller KL, et al. (2012) Dependence of $\beta 3$ adrenergic signaling on the adipokine leptin in cardiac myocytes. Int $J$ Obes (Lond) 36: 876-879. [Crossref]

445. Zalewska M, Siara M, Sajewicz W (2014) G protein-coupled receptors: abnormalities in signal transmission, disease states and pharmacotherapy. Acta Pol Pharm 71: 229243. [Crossref]

446. MracskoE, Liesz A, Karcher S, Zorn M, Bari F,et al (2014) Differential effects of sympathetic nervous system and hypothalamic-pituitary-adrenal axis on systemic immune cells after severe experimental stroke. Brain Behav Immun 41: 200-9. 
447. Fu Q, Kim S, Soto D, De Arcangelis V, DiPilato L, et al. (2014) A long lasting $\beta 1$ adrenergic receptor stimulation of cAMP/protein kinase A (PKA) signal in cardiac myocytes. J Biol Chem 289: 14771-14781. [Crossref]

448. Schreckenberg R, Maier T, Schlüter KD (2009) Post-conditioning restores preischaemic receptor coupling in rat isolated hearts. Br J Pharmacol 156: 901-908. [Crossref]

449. Triposkiadis F, Karayannis G, Giamouzis G, Skoularigis J, Louridas G, et al. (2009) The sympathetic nervous system in heart failure physiology, pathophysiology, and clinical implications. J Am Coll Cardiol 54: 1747-1762. [Crossref]

450. HeubachJF, Blaschke M, Harding SE, Ravens U, Kaumann AJ (2003) Cardiostimulan and cardiodepressant effects through overexpressed human beta2-adrenoceptors in murine heart: regional differences and functional role of beta1-adrenoceptors. Naunyn Schmiedebergs Arch Pharmacol 367: 38 0-90

451. DumasF, Bougouin W, Geri G, Lamhaut L, Bougle A, et al. (2014) Is epinephrine during cardiac arrest associated with worse outcomes in resuscitated patients? $\mathrm{J} \mathrm{Am}$ Coll Cardiol 64: 2360-7. [Crossref]

452. Krishnamoorthy V, Vavilala MS, Fettiplace MR, Weinberg G (2014) Epinephrine for cardiac arrest: are we doing more harm than good? Anesthesiology 120: 792-794. [Crossref]

453. MyslivecekJ, Rícný J, Kolár F, Tucek S (2003) The effects of hydrocortisone on rat heart muscarinic and adrenergic alpha, beta 1 and beta 2 receptors, propranololresistant binding sites and on some subsequent steps in intracellular signalling. Naunyn Schmiedebergs Arch Pharmacol 368: 366-76.

454. Yancy CW, Jessup M, Bozkurt B, Butler J, Casey D E J (2013) 2013 ACCF/AHA Guideline for the Management of Heart Failure: A Report of the American College of Cardiology Foundation/American Heart Association Task Force on Practice Guidelines. Circulation 62: e147-239. [Crossref]

455. Pober JS, Jane-wit D2, Qin L2, Tellides G2 (2014) Interacting mechanisms in the pathogenesis of cardiac allograft vasculopathy. Arterioscler Thromb Vasc Biol 34: 1609-1614. [Crossref]

456. Win TS, Rehakova S, Negus MC, Saeb-Parsy K, Goddard M, et al. (2009) Donor CD4 $\mathrm{T}$ cells contribute to cardiac allograft vasculopathy by providing help for autoantibody production. Circ Heart Fail 2: 361-369. [Crossref]

457. Larsen CP, Morris PJ, Austyn JM (1990) Migration of dendritic leukocytes from cardiac allografts into host spleens. A novel pathway for initiation of rejection. $J$ Exp Med 171: 307-314. [Crossref]

458. Wu X, Liu B-J, Ji S, Wu J-F, Xu C-Q, et al (2015) Social defeat stress promotes tumor growth and angiogenesis by upregulating vascular endothelial growth factor/ extracellular signal-regulated kinase/matrix metalloproteinase signaling in a mouse model of lung carcinoma. Mol Med Rep 12: 1405-12. [Crossref]

459. Pearsall P, Schwartz GE, Russek LG (2000) Changes in heart transplant recipients that parallel the personalities of their donors. Integr Med 2: 65-72. [Crossref]

460. Pearsall P, Schwartz GER, Russek LGS. (2002) Changes in Heart Transplant Recipients That Parallel the Personalities of Their Donors. J Near-Death Stud 20: 191-206. [Crossref]

461. Pearsall P, Schwartz GER, Russek LGS (2005) Organ Transplants and Cellular Memories. Nexus Magazine 12: 3.

462. Pearsall P, Schwartz GER, Russek LGS (2005).Organ Transplants and Cellular Memories.Nexus Magazine 12: 3 .

463. Mason JW (1975) A historical view of the stress field. J Human Stress 1: 22-36 concl. [Crossref]
464. Sterling P, Eyer J (1988) Alostasis: a new paradigm to explain arousal pathology Handbook of Life Stress, Cognition and Health. John Wiley and Sons; 629-49

465. Schulkin J (2003) Allostasis: a neural behavioral perspective. Horm Behav 43: 21-27. [Crossref]

466. Goldstein DS, Kopin IJ (2007) Evolution of concepts of stress. Stress 10: 109-120. [Crossref]

467. Goldstein DS (1995) Stress as a scientific idea - A homeostatic theory of stress and distress. Homeost Heal Dis 1995; 36: 177-215.

468. Sapolsky RM. Why zebras don't get ulcers. Holt Paperbacks; 3rd edition; 2004: 1-560.

469. Schulkin J (2011) Social allostasis: Anticipatory regulation of the internal milieu. Front Evol Neurosci 2. [Crossref]

470. Ziv Y, Schwartz M (2008) Immune-based regulation of adult neurogenesis: implications for learning and memory. Brain Behav Immun 22: 167-176. [Crossref]

471. McEwen BS1 (2006) Protective and damaging effects of stress mediators: central role of the brain. Dialogues Clin Neurosci 8: 367-381. [Crossref]

472. McEwen BS, Seeman T (1999) Protective and damaging effects of mediators of stress Elaborating and testing the concepts of allostasis and allostatic load. Ann N Y Acad Sci 896: 30-47. [Crossref]

473. McEwen BS (2002) Protective and damaging effects of stress mediators: the good and bad sides of the response to stress. Metabolism 51: 2-4. [Crossref]

474. Swaab DF, Bao AM, Lucassen PJ (2005) The stress system in the human brain in depression and neurodegeneration. Ageing Res Rev 4: 141-194. [Crossref]

475. Popoli M, Yan Z, McEwen BS, Sanacora G (2011) The stressed synapse: the impact of stress and glucocorticoids on glutamate transmission. Nat Rev Neurosci13: 22-37. [Crossref]

476. Kim JJ, Haller J (2007) Glucocorticoid hyper- and hypofunction: Stress effects on cognition and aggression. Ann N Y Acad Sci. 1113: 291-303. [Crossref]

477. Zhang Y, Woodruff M, Zhang Y, Miao J, Hanley G, et al. (2008) Toll-like receptor 4 mediates chronic restraint stress-induced immune suppression. J Neuroimmunol 194: 115-122. [Crossref]

478. Elenkov IJ (2004) Glucocorticoids and the Th1/Th2 balance. Ann N Y Acad Sci 1024 138-146. [Crossref]

479. Lutgendorf SK, Sood AK (2011) Biobehavioral factors and cancer progression: physiological pathways and mechanisms. Psychosom Med 73: 724-730. [Crossref]

480. Daly KA, Liu S, Agrawal V, Brown BN, Johnson SA, et al. (2012) Damage associated molecular patterns within xenogeneic biologic scaffolds and their effects on host remodeling. Biomaterials 33: 91-101. [Crossref]

481. van den Hoogen P, Huibers MM, Sluijter JP, de Weger RA (2015) Cardiac allograft vasculopathy: a donor or recipient induced pathology? J Cardiovasc Transl Res 8: 106-116. [Crossref]

482. Cho J-H, Lee I, Hammamieh R, Wang K, Baxter D, et al. (2014) Molecular evidence of stress-induced acute heart injury in a mouse model simulating posttraumatic stress disorder. Proc Natl Acad Sci U S A 111: 3188-3193. [Crossref]

483. Cárdenes N, Cáceres E, Romagnoli M, Rojas M (2013) Mesenchymal stem cells: a promising therapy for the acute respiratory distress syndrome. Respiration $85: 267-$ 278. [Crossref]

484. FOCUS marzo 2015. Focus Gruner Jahr/Arnoldo Mondadori Ed 2015; 6: 31.

Copyright: (C2015 Dal Lin. This is an open-access article distributed under the terms of the Creative Commons Attribution License, which permits unrestricted use, distribution, and reproduction in any medium, provided the original author and source are credited. 